NBER WORKING PAPER SERIES

\title{
EXCHANGE RATE VOLATILITY AND PRODUCTIVITY GROWTH: THE ROLE OF FINANCIAL DEVELOPMENT
}

\author{
Philippe Aghion \\ Philippe Bacchetta \\ Romain Ranciere \\ Kenneth Rogoff \\ Working Paper 12117 \\ http://www.nber.org/papers/w12117 \\ NATIONAL BUREAU OF ECONOMIC RESEARCH \\ 1050 Massachusetts Avenue \\ Cambridge, MA 02138 \\ March 2006
}

We would like to thank Jaume Ventura, Alan Stockman, Eric van Wincoop, Daron Acemoglu, and several participants at ESSIM 2005, the NBER Summer Institute 2005, and at seminars at Pompeu Fabra, PSE, Lausanne, and Zurich for useful comments. Luis Angeles and Guillermo Vuletin provided able research assistance. We acknowledge financial support from the Fondation Banque de France. The views expressed in this paper are those of the authors and do not necessarily represent those of the IMF or IMF policy. The views expressed herein are those of the author(s) and do not necessarily reflect the views of the National Bureau of Economic Research.

C2006 by Philippe Aghion, Philippe Bacchetta, Romain Ranciere and Kenneth Rogoff. All rights reserved. Short sections of text, not to exceed two paragraphs, may be quoted without explicit permission provided that full credit, including () notice, is given to the source. 
Exchange Rate Volatility and Productivity Growth: The Role of Financial Development Philippe Aghion, Philippe Bacchetta, Romain Ranciere and Kenneth Rogoff

NBER Working Paper No. 12117

March 2006

JEL No.

\begin{abstract}
This paper offers empirical evidence that real exchange rate volatility can have a significant impact on long-term rate of productivity growth, but the effect depends critically on a country's level of financial development. For countries with relatively low levels of financial development, exchange rate volatility generally reduces growth, whereas for financially advanced countries, there is no significant effect. Our empirical analysis is based on an 83 country data set spanning the years 1960-2000; our results appear robust to time window, alternative measures of financial development and exchange rate volatility, and outliers. We also offer a simple monetary growth model in which real exchange rate uncertainty exacerbates the negative investment effects of domestic credit market constraints. Our approach delivers results that are in striking contrast to the vast existing empirical exchange rate literature, which largely finds the effects of exchange rate volatility on real activity to be relatively small and insignificant.
\end{abstract}

\section{Philippe Aghion \\ Department of Economics \\ Harvard University \\ Cambridge, MA 02138 \\ and NBER \\ p_aghion@harvard.edu}

Philippe Bacchetta

Study Center Gerzensee

Dorfstrasse 2

P.O. Box 21

CH-3115 Gerzensee

SWITZERLAND

philippe.bacchetta@ szgerzensee.ch

\author{
Romain Ranciere \\ International Monetary Fund \\ 700 19th Street NW \\ Washington, DC 20431 \\ rranciere@imf.org
}

Kenneth Rogoff

Department of Economics

Harvard University

Cambridge, MA 02138

and NBER

krogoff@harvard.edu 


\section{Introduction}

Throughout the developing world, the choice of exchange rate regime stands as perhaps the most contentious aspect of macroeconomic policy. Witness, on the one hand, the intense international criticism of China's inflexible exchange rate system. On the other hand, South African policymakers are chastized for not doing enough to stabilize their country's highly volatile currency. Yet, despite the perceived centrality of the exchange rate regime to longrun growth and economic stability, the existing theoretical and empirical literature offers little guidance. The theoretical literature is mainly tailored to richer countries with highly developed institutions and markets (e.g., Garber and Svensson 1995 and Obstfeld and Rogoff, 1996), and there is almost no discussion of long-run growth. The empirical literature is largely negative, suggesting to some that the degree of exchange rate flexibility simply does not matter for growth, or for anything except the real exchange rate. ${ }^{1}$

In this paper, we develop and test a simple framework suggesting that a country's level of financial development ought to be central in choosing how flexible an exchange rate system to adopt, particularly if the objective is long-run productivity growth. Interestingly, we find striking and apparently robust evidence that the more financially developed a country is, the better it will do with a more flexible exchange rate. The volatility of real shocks relative to financial shocks - which features so prominently in the literature on developed country exchange rate regimes - also matters for developing countries. But because financial shocks tend to be greatly amplified in financially underdeveloped economies, one has to adjust calibrations accordingly.

Figure 1 shows the relationship between productivity growth and exchange rate flexibility for countries at different levels of financial development. The upper graphs consider the volatility of the effective real exchange rate and the lower graphs deal with the exchange rate

\footnotetext{
${ }^{1}$ The classic paper is Baxter and Stockman (1989). In their survey, Gosh, Gulde, and Wolf (2003) state that "perhaps the best one can say is that the growth performance of pegged regimes is no worse than that of floating regimes". More recent studies include Levy-Yeyati and Sturzenegger (2003), Razin and Rubinstein (2004), Husain, Mody and Rogoff (2005), De Grauwe and Schnabl (2005), and Dubas et al. (2005). Section 2 discusses this literature in more details. We note that Baldwin (1992), in his analysis of European Monetary Union, argued that a single currency might have growth effects on Europe by reducing the exchange rate premium on capital within Europe. Husain et al. (2005) argue informally that fixed rates may be more important for countries with more fragile political and financial institutions, but they do not provide any direct evidence for this view. There is some evidence of an effect of exchange rate volatility on trade levels (Frankel and Wei, 1993 and Rose, 2000). The effect, however, does not appear to be large and it is even less clear that the resulting trade expansion has any great impact on welfare (see Krugman, 1987, or Bacchetta and van Wincoop, 2000).
} 
regime classification proposed by Reinhart and Rogoff (2004). In each case, we compare the residuals of a productivity growth regression on a set of variables with the residuals of an exchange rate flexibility regression on the same variables. ${ }^{2}$ By doing so, we obtain adjusted measures of volatility and flexibility that are purged from any collinearity with the standard growth determinants. Countries are ranked in function of their financial development measured by private credit to GDP over five-year averages. The left-hand side of both Panels shows the lower quartile and the right-hand side shows the upper quartile of the distribution. There is clearly a negative relationship between productivity growth and exchange rate flexibility for less financially developed countries, while we see no relationship for the most developed economies.

We take the results in Figure 1 as preliminary evidence that the growth effects of real exchange rate volatility and the flexibility of the exchange rate regime vary with the level of financial development. The main purpose of this paper is to rationalize and then explore the robustness of this finding. In Section 2 we develop a model of an open monetary economy with wage stickiness, where exchange rate fluctuations affect the growth performance of creditconstrained firms. Exchange rate fluctuations in turn are caused by both real and financial aggregate shocks. The basic mechanism underlying the positive growth interaction between financial development and exchange rate volatility can be explained as follows. Suppose that the borrowing capacity of firms is proportional to their current earnings, with a higher multiplier reflecting a higher degree of financial development in the economy. Suppose in addition that the nominal wage is preset and cannot be adjusted to variations in the nominal exchange rate. Then, following an exchange rate appreciation, firms' current earnings are reduced, and so is their ability to borrow in order to survive idiosyncratic liquidity shocks and thereby innovate in the longer term. This, in turn, may help explain why in Figure 1 growth in countries with lower financial development benefits more from a fixed exchange rate regime. $^{3}$ We also show in Section 2 that the superior growth performance of a more stable

\footnotetext{
${ }^{2}$ We perform a pooled regression using five-year average data for 83 countries over 1970-2000. The controls include initial productivity, secondary schooling, financial depth, government expenditure, trade openness, term-of-trade growth and an indicator of banking and currency crises. The variables are defined in Section 2 and in the Appendix. For each quartile, we regress growth residuals on the adjusted measures of real exchange rate volatility and the flexibility of the exchange rate regime.

${ }^{3}$ A related explanation, which can be easily formalized in the context of our model, is that the lower financial development, the more the anticipation of exchange rate fluctuations should discourage R\&D investments. This would lower growth if these investments were to be decided before firms know the realization of the aggregate shock (since firms anticipate that with higher probability, their R\&D investment will not pay out in the long run as it will not survive the liquidity shock).
} 
exchange rate holds as long as the volatility of financial market shocks is large compared to the volatility of real shocks. However, the source of shocks only matters at lower levels of financial development.

In the second part of the paper, we test our theoretical predictions by conducting a systematic panel data analysis with a data set for 83 countries over the years 1960-2000. When a country's de facto degree of exchange rate flexibility is interacted with its level of financial development the results prove both robust and highly significant. We consider various measures of exchange rate flexibility, including the volatility of the real effective exchange rate and the exchange rate regime. We use the classification of Reinhart and Rogoff (2004) in the main analysis, but find that our results are generally robust to other de facto classifications. ${ }^{4}$ We consistently find that a high degree of exchange rate flexibility leads to lower growth in countries with relatively thin financial markets. Moreover, these effects are not only statistically significant, they appear quantitatively significant as well. For example, our estimates indicate that a country which lies in the middle of the lower quartile (e.g., Zambia in 1980), with credit to GDP of $15 \%$, would have gained 0.94 percent of annual growth had it switched from a flexible to a totally rigid exchange rate. Even a country in the middle of the second quartile (like Egypt in 1980), with credit to GDP of about 27\%, would have gained 0.43 percent growth per year by adopting a uniform pegged exchange rate. Our core results appears to hold intact against a variety of standard robustness tests, including attempts to quarantine the results against outliers and regional effects and allowing for alternative control variables. We also consider alternative measures of exchange rate volatility, as well as considering distance to the technological frontier as both alternative, and supplementary, interaction variables. Finally, we adopt a variety of approaches to addressing the problem of exchange regime endogeneity, both using techniques within our GMM methodology and by examining the broader historical evidence on the choice of exchange rate regime.

Our results markedly depart from the dominant view of an exchange rate "disconnect" (Obstfeld and Rogoff, 2001), and in doing so they suggest new directions for research on the choice of exchange rate regime. For example, we show that while exchange rate flexibility has the desirable property of dampening the impact of real shocks, on average it still has a negative impact of productivity growth in less financially developed economies.

The remaining part of the paper is organized as follows. Section 2 presents the model and

\footnotetext{
${ }^{4}$ The classification of Reinhart and Rogoff is more appropriate in our context, since they focus mainly on exchange rate volatility, in particular including dual and multiple exchange rates. Other classifications, such as Levy-Yeyati and Sturzenegger (2003), capture better the constraints on monetary policy by including changes in reserves in defining their classification. However, our focus is on exchange rate volatility.
} 
derives the theoretical predictions. Section 3 develops our empirical analysis and results. The data are detailed in an appendix, which also includes the results of further robustness tests.

\section{A Simple Model}

The model in this section combines three main elements. First, productivity grows as a result of innovation by those entrepreneurs with sufficient funds to meet short-run liquidity shocks. This feature is similar to Aghion, Angeletos, Banerjee, and Manova (2005). Second, macroeconomic volatility is driven by nominal exchange rate movements in presence of wage stickiness. This monetary feature borrows from the recent New Open Economy Macroeconomics literature. We assume that the central bank either fixes the nominal exchange rate or lets it float and follows an interest rate rule. Third, the exchange rate is imperfectly correlated with other macroeconomic variables, e.g., aggregate productivity, which in turn is consistent with the evidence. We model this by introducing risk premium shocks that are exogenous to the real economy. Thus, exchange rate volatility depends upon both the variance of real shocks and that of risk premium shocks.

\subsection{A small open economy with sticky wages}

We consider a small open economy populated by successive overlapping generations of twoperiod lived entrepreneurs and workers. The economy produces a single good identical to the world good. One half of the individuals are selected to become entrepreneurs, while the other half become workers. Individuals are risk neutral and consume their accumulated income at the end of their life. Growth will be determined by the proportion of entrepreneurs who innovate.

Since firms in the small domestic economy are price-takers, they take the foreign price of the good at any date $t, P_{t}^{*}$, as given. Assuming purchasing power parity (PPP), converted back in units of the domestic currency, the value of one unit of sold output at date $t$ is equal to:

$$
P_{t}=S_{t} P_{t}^{*}
$$

where $P_{t}$ is the domestic price level and $S_{t}$ is the nominal exchange rate (number of units of the domestic currency per unit of the foreign currency). We will assume that $P_{t}^{*}$ is constant and normalize it to $1 .^{5}$ Thus, $P_{t}=S_{t}$.

\footnotetext{
${ }^{5}$ We implicitly assume that the foreign country strictly targets the price level.
} 
In a fixed exchange rate regime, $S_{t}$ is constant, whereas under a flexible exchange rate regime $S_{t}$ is random and fluctuates around its mean value $E\left(S_{t}\right) \equiv \bar{S} .{ }^{6}$ The reason why fluctuations in the nominal exchange rate $S_{t}$ will lead to fluctuations in firms' real wealth, with consequences for innovation and growth, is that nominal wages are rigid for one period and preset before the realization of $S_{t}$. This in turn exposes firms' short-run profits to an exchange rate risk as the value of sales will vary according to $S_{t}$ whereas the wage bill will not. $^{7}$

For simplicity, we take the wage rate at date $t$ to equate the real wage at the beginning of that period to some reservation value, $k A_{t}$. The parameter $k<1$ refers to the workers' productivity-adjusted reservation utility, say from working on a home activity, and $A_{t}$ is current aggregate productivity which we first assume to be non-random. We thus have:

$$
\frac{W_{t}}{E\left(P_{t}\right)}=k A_{t}
$$

where $W_{t}$ is the nominal wage rate preset at the beginning of period $t$ and $E\left(P_{t}\right)$ is the expected price level. Using the fact that $E\left(P_{t}\right)=E\left(S_{t}\right)=\bar{S}$, we immediately get

$$
W_{t}=k \bar{S} A_{t}
$$

\subsection{The behavior of firms}

Individuals who become entrepreneurs take two types of decisions. ${ }^{8}$ First, at the beginning of their first period, they need to decide how much labor to hire at the given nominal wage; this decision occurs after the aggregate shocks are realized. Second, at the end of their first period entrepreneurs face a liquidity shock and must decide whether or not to cover it (if they can) in order to survive and thereby innovate in the second period. The proportion $\rho_{t}$ of entrepreneurs who innovate determines the growth rate of this economy. We first describe production and profits and then consider these two decisions in turn.

\footnotetext{
${ }^{6} \mathrm{~A}$ constant foreign interest rate can be justified if we assume a technology with constant real return $r^{*}$. Since there is no inflation in the foreign country we have $i^{*}=r^{*}$.

${ }^{7}$ In this benchmark model, the interesting measure of the real exchange rate is based on labor costs. The real rate based on price levels becomes of interest once we introduce non-traded goods or distribution services. That real exchange rates are more volatile under a flexible exchange rate regime is documented in Appendix D.

${ }^{8}$ One can easily extend the model so as to allow firms to increase the probability of innovation by investing more in R\&D ex ante.
} 


\subsubsection{Production and profits}

The production of an entrepreneur born at date $t$ in her first period, is given by

$$
y_{t}=A_{t} \sqrt{l_{t}}
$$

where $l_{t}$ denotes the firm's labor input at date $t .^{9}$

Given current nominal wages, nominal profits at the end of her first period are given by

$$
\Pi_{t}=P_{t} y_{t}-W_{t} l_{t}=A_{t} S_{t} \sqrt{l_{t}}-k A_{t} \bar{S} l_{t}
$$

In her second period, the entrepreneur innovates and thereby realizes the value of innovation $v_{t+1}$, with probability $\rho_{t}$ which depends upon whether the entrepreneur can cover her liquidity cost at the end of her first period. As we shall see, in an economy with credit constraints, the latter depends upon the short-term profit realization and therefore upon both employment and the aggregate shocks in the first period.

Employment in the first period is then chosen by the entrepreneur in order to maximize her net present value:

$$
\max _{l_{t}}\left\{A_{t} P_{t} \sqrt{l_{t}}-k A_{t} \bar{S} l_{t}+\beta \rho_{t} E_{t} v_{t+1}\right\}
$$

where $\beta$ denotes the entrepreneur's discount rate.

\subsubsection{Innovation, liquidity shocks and credit constraints}

Innovation upgrades the entrepreneur's technology up by some factor $\gamma>1$, so that a successful innovator has productivity $A_{t+1}=\gamma A_{t}$. It is natural to assume that the value of innovation $v_{t+1}$ is proportional to the productivity level achieved by a successful innovator, that is

$$
v_{t+1}=v P_{t+1} A_{t+1},
$$

with $v>0$.

Next, we assume that innovation occurs in any firm $i$ only if the entrepreneur in that firm survives the liquidity shock $C_{t}^{i}$ that occurs at the end of her first period. Absent credit constraints, the probability of overcoming the liquidity shock would be equal to one, if the value of innovation is larger than the cost, and to zero otherwise. In either case, this probability would be independent of current profits. However, once we introduce credit constraints, the probability of the entrepreneur being able to innovate will depend upon her current cash-flow and therefore upon the choice of $l_{t}$.

\footnotetext{
${ }^{9}$ Our choice of production technology is made for analytical simplicity, but at the end of this section we discuss how our model and results extend to more general settings.
} 
We assume that the liquidity cost of innovation is proportional to productivity $A_{t}$, according to the following linear form (multiplied by $P_{t}$ as it is expressed in nominal terms):

$$
C_{t}^{i}=c^{i} P_{t} A_{t}
$$

where $c^{i}$ is independently and identically distributed across firms in the domestic economy, with cumulative distribution function $F$ which we assume to be strictly concave over the interval between 0 and $\bar{c}$. While all firms face the same probability distribution over $c^{i}$ ex ante, ex post the realization of $c^{i}$ differs across firms. We assume that the net productivity gain from innovating (e.g., as measured by $v \gamma$ ) is sufficiently high that it is always profitable for an entrepreneur to try and overcome her liquidity shock.

In order to pay for her liquidity cost, the entrepreneur can borrow on the local credit market. However, credit constraints will prevent her from borrowing more than a multiple $\mu-1$ of current cash flow $\Pi_{t}$. We take $\mu$ as being the measure of financial development and we assume that is it constant. ${ }^{10}$ The borrowing constraint is no longer binding if $\mu$ becomes large.

Thus, the funds available for innovative investment at the end of the first period are at most equal to

$$
\mu \Pi_{t}
$$

and therefore the entrepreneur will innovate whenever:

$$
\mu \Pi_{t} \geq C_{t}^{i}
$$

Thus, the probability of innovation $\rho_{t}$ is equal to ${ }^{11}$

$$
\rho_{t}=F\left(\frac{\mu \Pi_{t}}{S_{t} A_{t}}\right)
$$

\subsubsection{Equilibrium profits}

Now, we can substitute for $\rho_{t}$ in the entrepreneur's maximization problem. The entrepreneur will choose $l_{t}$ to maximize (4) which yields

$$
l_{t}=\left(\frac{S_{t}}{2 k \bar{S}}\right)^{2}
$$

and therefore

$$
\Pi_{t}=\psi A_{t} S_{t}^{2},
$$

\footnotetext{
${ }^{10}$ If $\mu$ was endogenous, it would decrease with more volatile profits, thus reinforcing the negative impact of exchange rate volatility.

${ }^{11}$ We always have $\rho_{t}>0$ since $\Pi_{t}>0$ in equilibrium and $S_{t}>0$.
} 
where $\psi \equiv 1 /(4 k \bar{S})$. We thus see that equilibrium profits are increasing in the nominal exchange rate $S_{t}$.

Next, from (6), we can express the probability of innovation as:

$$
\rho_{t}=F\left(\mu \psi S_{t}\right)
$$

\subsection{Productivity growth and the main theoretical prediction}

Expected productivity at date $t+1$ is equal to:

$$
E\left(A_{t+1}\right)=E\left(\rho_{t}\right) \gamma A_{t}+\left(1-E\left(\rho_{t}\right)\right) A_{t}
$$

The expected rate of productivity growth between date $t$ and date $(t+1)$, is correspondingly given by

$$
g_{t}=\frac{E\left(A_{t+1}\right)-A_{t}}{A_{t}}=(\gamma-1) E\left(\rho_{t}\right)
$$

We can then establish:

Proposition 1 Moving from a fixed to a flexible exchange rate reduces average growth; the growth gap goes to zero as financial development measured by $\mu$ becomes large.

Proof: From (9), the average growth rate $g_{t}$ is proportional to the expected proportion of innovating firms. Thus, to compare a fixed exchange rate (i.e., no exchange rate volatility) with a flexible rate, we just need to look at the difference between the corresponding expected innovation probabilities:

$$
\Delta_{t}=\bar{\rho}-E\left(\rho_{t}\right)
$$

where

$$
\bar{\rho}=F(\mu \psi \bar{S})
$$

and

$$
E\left(\rho_{t}\right)=E\left(F\left(\mu \psi S_{t}\right)\right)
$$

The first part of the proposition follows immediately from the concavity of $F$. And the second part follows from the fact that both $F(\mu \psi \bar{S})$ and $E\left(F\left(\mu \psi S_{t}\right)\right)$ converge to 1 as $\mu$ goes to infinity.

Remark 1: Convergence: The model can be turned into a convergence model, for example by assuming that innovating firms catch up with a world technology frontier growing at some rate $\bar{g}$, at a cost which is proportional to the world frontier productivity. Based upon the convergence analysis in Aghion, Howitt, and Mayer (2005), we conjecture that the lower the 
degree of financial development in a country, the more likely it is that higher exchange rate volatility will prevent the country from converging to the world technological frontier in growth rates and/or in per capita GDP levels.

Remark 2: More general cost distributions and production technologies: Proposition 1 makes use of the concavity of the cumulative distribution function on liquidity shocks $F$. First, note that this assumption is satisfied, at least over large intervals, for a large class of density functions. Second, even if this assumption is violated, or with more general production technologies, Proposition 1 holds as long as $\bar{\rho}$ is sufficiently close to one. The intuition is very simple: in this case, more volatility around $\bar{S}$ implies essentially the same ability to overcome the liquidity shocks in a boom when $S_{t}$ is high, whereas it implies lower values of $S_{t}$ and therefore a lower survival probability $\rho_{t}$ in slumps, all the lower when $\mu$ is smaller. It then follows immediately that $\bar{\rho}-E\left(\rho_{t}\right)$ must be positive. Finally, when $\bar{\rho}<<1$, then there is the possibility that more volatility could stimulate innovation and thereby productivity growth in expansions, which we refer to as a "gambling for resurrection" effect. However, Figure 1 and our regressions in the next section suggest that this latter effect is dominated.

\subsection{On the stabilizing role of flexible exchange rates}

Even though the exchange rate is more volatile than other fundamentals, it is endogenous and is potentially correlated with other variables. In this section, we sketch a simple general equilibrium model where the nominal exchange rate reacts to productivity and risk premium shocks. Assume that domestic productivity is random and can be expressed as:

$$
A_{t}=\bar{A}_{t} e^{u_{t}}
$$

where: (i) $\bar{A}_{t}$ is the country's level of knowledge at date $t$, which in turn results from innovations in period $t-1$, according to:

$$
\bar{A}_{t}=\left(\rho_{t-1}(\gamma-1)+1\right) A_{t-1}
$$

(ii) $u_{t}$ is a productivity shock with mean $E\left(u_{t}\right)=0$ and variance $\sigma_{u}^{2}$.

We assume that the nominal wage is set before the productivity shock is known. Thus, analogously to equation (2) we have $W_{t}=k \overline{S A}_{t}$. It is easy to show that equation (7) is replaced by:

$$
\Pi_{t}=\bar{\psi}_{t} A_{t}^{2} S_{t}^{2},
$$

where $\bar{\psi}_{t} \equiv 1 /\left(4 k \overline{S A}_{t}\right)$. Thus, the probability of innovation is given by:

$$
\rho_{t}=F\left(\mu \bar{\psi}_{t} A_{t} S_{t}\right)
$$


This probability is determined by the volatility of the product $A_{t} S_{t}$.

We now describe the exchange rate behavior. Arbitrage between domestic and foreign bonds by foreign investors yields the following interest parity condition (expressed in logs):

$$
s_{t}=s_{t+1}^{e}+\ln \left(1+i^{*}\right)-\ln \left(1+i_{t}\right)+\eta_{t}
$$

where $i_{t}$ and $i^{*}$ represent domestic and foreign nominal interest rates (on one-period bonds) and $s_{t}=\ln S_{t}$. The foreign interest rate is taken as given and assumed to be constant. The variable $\eta_{t}$ represents a time-varying risk premium determined by investors in the foreign exchange market. Risk-premium shocks are introduced to model the "disconnect" between nominal exchange rate variations and other fundamental variables. ${ }^{12}$ The variance of the risk premium is $\sigma_{\eta}^{2}$ and we assume that $E\left(\eta_{t}\right)=0$ and $\operatorname{cov}\left(\eta_{t}, u_{t}\right)=0$.

For notational simplicity, we assume that when the exchange rate regime is fixed, it is set at $s_{t}=0$. When the exchange rate regime is flexible, the central bank follows an interest rate rule and the exchange rate is determined by the market. ${ }^{13}$ In order to stabilize profits, the central bank reacts to exchange rate shocks (equivalent to price level shocks) and to productivity shocks. ${ }^{14}$ The rule takes the form:

$$
\ln \left(1+i_{t}\right)=\phi_{0}+\phi_{1} \cdot s_{t}+\phi_{2} \cdot u_{t}
$$

where we assume that $\phi_{0}=\ln \left(1+i^{*}\right)$ and that $\phi_{1}$ and $\phi_{2}$ are given.

By substituting this rule back into (13), integrating forward and ruling out speculative bubbles, we find that the equilibrium exchange rate can be expressed as:

$$
s_{t}=\frac{1}{1+\phi_{1}} \eta_{t}-\frac{\phi_{2}}{1+\phi_{1}} u_{t}
$$

In particular, we see that the exchange rate reacts negatively to productivity shocks.

\footnotetext{
${ }^{12}$ Risk-premium shocks come from the behavior of investors who trade for reasons other than the rationally expected return. For example, Jeanne and Rose (2002) and Devereux and Engel (2003) assume that some traders have biased expectations; Duarte and Stockman (2005) assume shocks to perceived covariances; and Bacchetta and van Wincoop (2006) assume hedging trade. The latter show that when investors have heterogenous information, small shocks to hedging trade have a large impact on the exchange rate.

${ }^{13}$ Our focus in this section is on comparing the impact of different exchange rate regimes on productivity growth, rather than examining the factors that lead a country to choose one or the other regime. In practice, economic ideology, history, political considerations and many other "exogenous" factors almost surely play a role in the choice of exchange rate regime, yet analyzing them goes behind the scope of this paper.

${ }^{14}$ See Woodford (2003) for a discussion of interest rate rules and Kollman (2002) and Obstfeld (2004) for an application in an open-economy context. Kollman also introduces risk premium shocks to generate more realistic exchange rate volatility.
} 
Since the probability of innovation is determined by the volatility of $A_{t} S_{t}$, we need to compare this volatility under fixed and flexible exchange rates. It is easy to show that the growth gap between fixed and flexible rates increases with the relative variances of risk premium to productivity shocks, $\sigma_{\eta}^{2} / \sigma_{u}^{2} \cdot{ }^{15}$ Moreover, when productivity shocks are large compared to risk premium shocks, a flexible rate gives higher growth. More precisely, expected growth $E\left(\rho_{t}\right)$ is higher under a flexible exchange rate when:

$$
\sigma_{u}^{2}>\varkappa \sigma_{\eta}^{2}
$$

where $\varkappa=1 /\left[\phi_{2}\left(2\left(1+\phi_{1}\right)-\phi_{2}\right)\right]$. Thus, Proposition 1 holds as long as the volatility of productivity shocks is not too large relative to the volatility of risk premium shocks. When real shocks dominate in the foreign exchange market, a flexible exchange rate may be preferred. ${ }^{16}$ However, the source of shocks only matters at low levels of financial development: when $\mu$ is very large the growth gap between fixed and flexible rates goes to zero independently of the source of shocks.

\section{Empirical Analysis}

Previous studies have shown that financial development fosters growth and convergence, conditions macroeconomic volatility, or may play a crucial role in financial crises. An interesting question is whether the level of financial development also conditions the impact of monetary arrangements, such as the exchange rate regime. Our basic hypothesis is that the exchange rate regime, or more generally exchange rate volatility, has a negative impact on (long-run) growth when countries are less developed financially.

To test these predictions, we consider standard growth regressions to which we add a measure of exchange rate flexibility, as well as an interaction term with exchange rate flexibility and financial development or some other measures of development. In this section, we consider three measures related to exchange rate flexibility: i) the exchange rate regime based on the natural classification of Reinhart and Rogoff (2004), henceforth RR; ii) the standard deviation

\footnotetext{
${ }^{15}$ Under a fixed exchange rate, we simply have $\ln A_{t} S_{t}=\ln \bar{A}_{t}+u_{t}$, while under a flexible rate we have $\ln A_{t} S_{t}=\ln \bar{A}_{t}+\left[\left(1+\phi_{1}-\phi_{2}\right) u_{t}+\eta_{t}\right] /\left(1+\phi_{1}\right)$. We can simply compare $\operatorname{var}\left(\ln A_{t} S_{t}\right)$ in each case.

${ }^{16}$ Notice that we ignore the impact of interest rate volatility. It is usually argued that interest rates are more volatile under a fixed exchange rate. This would be true in our model if $\sigma_{\eta}^{2}$ is the same across regimes. However, it is seems likely that $\sigma_{\eta}^{2}$ is lower under a peg. Empirically, interest rates do not appear much more volatile under fixed exchange rates. We found the following nominal interest volatility in our sample: peg: 6.2\%; limited flex: 9.2\%; managed float: 9.4\%; float: 5.4\%. Using another classification, Shambaugh (2004) finds that interest rates are more volatile under flexible rates.
} 
of the real effective exchange rate; iii) the degree of real "overvaluation", as a deviation of the real exchange rate from its long-term value. We also examine the interaction between termsof-trade shocks, the exchange rate regime, and growth. We first present the methodology and the variables used and then the results based on a dynamic panel of 83 countries over the 1960-2000 period.

\subsection{Data and methodology}

As is now standard in the literature, we construct a panel data set by transforming our time series data into five-year averages. This filters out business cycle fluctuations, so we can focus on long-run growth effects. Our dependent variable is productivity growth, rather than total growth. We use the GMM dynamic panel data estimator developed in Arellano and Bond (1991), Arellano and Bover (1995) and Blundell and Bond (1997) and we compute robust twostep standard errors by following the methodology proposed by Windmeijer (2004). ${ }^{17}$ This approach addresses the issues of joint endogeneity of all explanatory variables in a dynamic formulation and of potential biases induced by country specific effects. The panel of country and time-period observations is unbalanced. Appendix B presents the list of countries included in the sample.

Our benchmark specification follows Levine, Loayza and Beck (2000) who provide evidence of a growth enhancing effect of financial development; they were the first to use the system GMM estimation we are using. We consider productivity growth instead of total growth, but our regressions are estimated with the same set of control variables. ${ }^{18}$ Starting from this benchmark, we examine the direct effect on growth of our exchange rate flexibility measures. Then, we look at the interaction between these measures and the level of financial development. More specifically, we estimate the following equation:

$$
y_{i, t}-y_{i, t-1}=(\alpha-1) y_{i, t-1}+\gamma_{1} E R_{i, t}+\gamma_{2} E R_{i, t} * I_{i, t}+\delta I_{i, t}+\beta^{\prime} Z_{i, t}+\mu_{t}+\eta_{i}+\varepsilon_{i, t}
$$

\footnotetext{
${ }^{17}$ It has been recognized that the two-step standard errors are downward biased in a small sample and the Windmeijer (2004) method corrects for that. Notice that, as the two-step estimator is asymptotically efficient, this approach is superior to just relying on first step estimates and standard errors as is common in the empirical growth literature that uses small samples. See Bond (2002) for a simple description of the methodology we follow.

${ }^{18}$ See their table 5, page 55. The other differences with Levine et al. (2000) are that we use a larger data set, we use the Windmejer standard errors, and we include a financial crisis dummy. Loayza and Ranciere (2005) show that their results stay unchanged when the original panel is extended to 83 countries over 1960-2000 and when a crisis dummy is introduced. Levine et al. (2000) show similar results when the same equation is estimated in cross-section with legal origin as external instrument.
} 
where $y_{i, t}$ is the logarithm of output per worker; $E R_{i, t}$ is either the degree of flexibility of the exchange rate regime, real exchange rate volatility, or a measure of overvaluation; $I_{i, t}$ is the dimension of interaction, i.e., financial development; $Z_{i t}$ is a set of other control variables, $\mu_{t}$ is the time-specific effect, $\eta_{i}$ is the country-specific effect, and $\varepsilon_{i, t}$ is the error term.

Our hypothesis is that $\gamma_{1}<0$ and $\gamma_{2}>0$ so that the impact of exchange rate flexibility $\gamma_{1}+\gamma_{2} * I_{i, t}$ is more negative at low levels of financial development. Moreover, when $\gamma_{1}$ and $\gamma_{2}$ have opposite signs, a threshold effect arises:

$$
\frac{\delta\left(y_{i, t}-y_{i, t-1}\right)}{\delta E R_{i, t}}=\gamma_{1}+\gamma_{2} I_{i, t}>0 \Leftrightarrow I_{i, t}>\widetilde{I}:=-\frac{\gamma_{1}}{\gamma_{2}}
$$

In Tables 1 to 3, we report threshold levels of financial development above which a more flexible exchange rate becomes growth enhancing. The standard errors of the respective threshold levels are computed using a delta method, that is by taking a first order Taylor approximation around the mean. Notice that in small samples, the delta method is known to result in excessively large standard errors.

We use three measures for the variable $E R_{i, t}$. First, we compute an index of flexibility of the exchange rate regime in each five-year period based on the $\mathrm{RR}$ exchange rate classification. Ignoring the free falling category, the RR annual natural broad classification orders regimes from the most rigid to the most flexible: $E R R_{t} \in\{1,2,3,4\}=\{$ fix, peg, managed float, float $\}$. Hence, we construct the index of exchange rate flexibility in each five-year interval as: ${ }^{19}$

$$
\text { Flex }_{t, t+5}=\frac{1}{5} \sum_{i=1}^{5} E R R_{t+i}
$$

The second measure we consider for $E R_{i, t}$ is the five-year standard deviation of annual $\log$ differences in the effective real exchange rate. We construct the effective rate as a tradeweighted index of multilateral real rates as explained in Appendix A. The third measure is the five-year average deviation from a predicted level of the real effective exchange rate. ${ }^{20}$

For the interaction variable $I_{i, t}$ we consider financial development measured as in Levine, Loayza and Beck (2000) by the aggregate private credit provided by banks and other financial institutions as a share of GDP. The dependent variable is growth in real GDP per worker. Our set of control variables includes average years of secondary schooling as a proxy for human

\footnotetext{
${ }^{19}$ The information on the flexibility of exchange rate is reported for each country-5 years interval during which the RR classification indicates a non free falling regime for at least 3 out of 5 years.

${ }^{20}$ We compute the average log difference between the actual exchange rate and the exchange rate predicted by country and time specificic characteristics (income per capita, population densisty, regional and time dummies) as in Dollar (1992). We also considered average log differences from a HP detrended multilateral exchange rate series as in Goldfajn and Valdes (1999), and found similar results.
} 
capital, inflation and the size of the government (government expenditure as proportion of GDP) to control for macroeconomic stability, and an adjusted measure of trade openness. ${ }^{21}$ A dummy indicating the frequency of a banking or a currency crisis within each five-year interval is introduced in the robustness checks. This indicator controls for rare but severe episodes of aggregate instability likely to be associated with large changes in the variables of interest. $^{22}$ Definition and sources for all variables are given in Appendix C.

\subsection{Exchange rate flexibility and financial development}

Tables 1, 2 and 3 present the estimations of the impact of the exchange rate regime, exchange rate volatility and real overvaluation on productivity growth. Each table displays the results of four regressions. The first regression estimates the effects of the exchange rate measure along with financial development and a set of control variables, without interaction term. The second regression adds a variable interacting the exchange rate measure and the measure of financial development in order to test our main prediction: the presence of a non-linear effect of exchange rate volatility on growth depending on the level of financial development. The third and fourth regressions replicate the same regressions with the addition of a dummy variable indicating the frequency of a currency or banking crisis in the five-year interval.

In Table 1, regression [1.1] illustrates the absence of a linear effect of the exchange rate regime on productivity growth. This result is consistent with many previous studies. In contrast, regression [1.2] shows that the interaction term of exchange rate flexibility and financial development is positive and significant. The more financially developed an economy is, the higher is the point estimate of the impact of exchange rate flexibility on productivity growth. Furthermore, the combined interacted and non-interacted coefficient of flexibility becomes significant at the $5 \%$ level (as indicated by the Wald Test in Table 1). Combining these two terms enables us to identify a threshold of financial development below (above) which a more rigid (flexible) regime fosters productivity growth. The point estimate of the threshold is close to the sample mean of the financial development measure. In regressions [1.3] and [1.4], we introduce the crisis dummy described above. While the frequency of crisis indeed has a negative impact on productivity growth, the non-linear effect of exchange rate regime on growth remains robust and its point estimate stays almost unchanged.

\footnotetext{
${ }^{21}$ More precisely we use the residuals of a pooled regression of (imports + exports)/GDP against structural determinants of trades such as landlock situation, an oil producers dummy, and population.

${ }^{22}$ For instance, Loayza and Hnakovska (2003) present evidence that crisis volatility can explain an important part of the negative relashionship between volatility and growth observed in middle-income economies.
} 
The main result of Table 1 is that letting the degree of exchange rate flexibility vary with the level of financial development allows us to identify significant growth effects of the exchange rate regime. The implication is that less financially developed economies may derive growth benefits from maintaining a rigid exchange rate regime. As illustrated by the examples given in the Introduction, these benefits can be economically large. This result provides a novel rational interpretation for the "fear of floating" behavior based on long run productivity growth.

Table 2 presents similar results with exchange rate volatility measured by the five-year volatility of the change in multilateral real exchange rates. Regression [2.1] indicates that exchange rate volatility has a significant negative impact on productivity growth. This effect is economically important: an increase of 50 percent in exchange rate volatility - which corresponds to the mean difference in volatility between a fixed and a flexible exchange rate (see Appendix D) - leads to a 0.33 percent reduction in annual productivity growth. This effect is only marginally reduced when we control for the impact of a crisis, as in regression [2.3]. Regression [2.2] shows that the interaction between exchange rate volatility and financial development is positive and significant: the more financially developed an economy is, the less adversely it is affected by exchange rate volatility. Here again, the economic impact is important. For instance, consider Chile, whose level of financial depth ranges from $10 \%$ in 1975 to $70 \%$ in 2000 . This drastic change decreases the negative impact of exchange rate volatility on growth by a factor of five. Moreover, our estimate indicates that exchange rate volatility exhibits no significant impact on productivity growth for the set of the financially most developed economies. ${ }^{23}$

Table 3 presents regressions that focus on the effect of real exchange rate overvaluation. We present the results using the deviation between the actual effective real exchange rate and its predicted value. ${ }^{24}$ In the baseline regression [3.1], real overvaluation has a significant and economically important negative effect on growth: a $20 \%$ overvaluation translates into a reduction of $0.2 \%$ in annual productivity growth (computed from regression [3.1] as $0.99 * \ln (120 / 100))$. Regression [3.2] studies the effect of interacting real overvaluation and financial development and shows that the more financially developed an economy is, the less vulnerable it becomes to real overvaluation. Using the previous example, a change in financial depth comparable to the one experienced by Chile over 1975-2000 results in a reduction by

\footnotetext{
${ }^{23}$ These are countries with a private credit to GDP ratio in the range of $[90 \%, 120 \%]$. This includes the euro aera, the U.K., Switzerland, Finland, Sweden, the US, and Australia.

${ }^{24}$ We obtain similar results when we consider HP deviation from trend when - as in Golfajn and Valdes (1999) - the HP filter parameter is set high enough (lamba=10 $\left.{ }^{8}\right)$.
} 
two of the negative effect of real overvaluation on productivity growth.

\subsection{Terms-of-trade growth and exchange rate flexibility}

It is often argued that a flexible exchange rate regime is desirable since it can stabilize the effects of real shocks. In subsection 2.4, we showed that a flexible exchange rate can indeed lead to higher growth when the variance of real shocks is large. Moreover, there is recent empirical evidence showing that flexible exchange rate regimes tend to absorb the effects of terms-of-trade shocks (see Broda, 2004, and Edwards and Levy-Yeyati, 2005). We examine this issue by including terms-of-trade growth and terms-of-trade volatility in our previous regressions and present the results in Table 4.

In regression [4.1], a $10 \%$ deterioration in the terms of trade leads to a reduction of $0.9 \%$ in productivity growth. ${ }^{25}$ In regression [4.2], we find that the impact on productivity growth of a terms-of-trade shock crucially depends on the nature of the exchange rate regime. It is larger under a fixed exchange rate regime and close to zero under a floating regime. This result confirms the stabilizing role of flexible exchange rates. However, in regression [4.3], we show that this stabilization effect fully coexists with the growth enhancing effect of a more fixed regime at low level of financial development. Thus, the empirical evidence shows that even though exchange rate flexibility dampens the impact of terms-of-trade shocks, it has a negative overall impact on growth for financially less developed countries since on average, terms-of-trade growth is close to zero.

In regression [4.4], we show that terms-of-trade volatility has a negative effect on productivity growth: a one standard deviation increase in terms-of-trade volatility reduces growth by 0.4 percentage point. In regression [4.5], we find that a more flexible exchange rate regime dampens the negative impact of terms-of-trade volatility. In fact, the total effect of termsof-trade volatility on productivity growth becomes close to zero under a fully flexible regime. In regression [4.6], we find that the interaction of exchange flexibility with financial development and with terms-of-trade volatility are both positive and significant suggesting that both variables condition the impact of exchange rate flexibility on productivity growth. However, even under the assumption of large terms-of-trade volatility - set at the 75th percentile of the variable sample distribution- a more fixed exchange regime is growth enhancing for countries in the lowest quartile of financial development. ${ }^{26}$

\footnotetext{
${ }^{25}$ Our findings confirms the results of Mendoza (1997) who show that both negative terms-of-trade change and terms-of-trade uncertainty lower economic growth.

${ }^{26}$ The 75 th percentile of the sample distribution of terms-of-trade volatility in $\log$ is 2.38 and the 25 th
} 


\subsection{Endogeneity issues}

At this point, the main qualification to our results would seem to be the standard question of endogeneity. To examine whether this is a serious issue in our context, we can i) make various test within our GMM methodology and ii) examine the broader existing empirical evidence on the determinants of exchange rate regimes or exchange rate volatility. Both perspectives indicate that endogeneity is not a major factor behind our results. First, our dynamic panel procedure using the GMM system estimator controls for the potential endogeneity of all the explanatory variables and accounts explicitly for the biases induced by including the initial level of productivity in the growth regressors. It is true that the estimation procedure is valid only under the assumption of weak exogeneity of the explanatory variables. That is, they are assumed to be uncorrelated with future realizations of the error term. We can test this assumption by a Sargan test of overidentification which evaluates the entire set of moment conditions in order to assess the overall validity of the instruments. The results of the Sargan test in Tables 1 to 4 show that the validity of the instruments cannot be rejected. ${ }^{27}$

Nevertheless, as pointed by Baum and al. (2003), the Sargan test may fail to detect the lack of validity of a subset of instruments. We address this issue through two robustness checks. First, we use "difference-in-Sargan" statistics to directly test the validity of subsets of orthogonality conditions. We could not reject the validity of any particular subset of instruments. Second, we re-estimate our baseline regression by substituting in the instrument matrix the second lag level by the third lag level of the explanatory variables. ${ }^{28,29}$ This estimation yields very similar results and insures that our results are not biased by the presence of some omitted variables that could be correlated with exchange rate flexibility and have an independent effect on next period innovation in productivity growth.

Furthermore, our empirical approach has several features that makes it less vulnerable percentile of the sample distribution of financial development in log is 2.65. The total growth effect of exchange rate flexibility, moving up one step in the RR classification, for a country with such levels of terms-of-trade volatility and financial development is therefore $-2.748+0.476 * 2.38+0.525 * 2.6=-0.25$.

${ }^{27} \mathrm{~A}$ second test examines whether the differenced error term is second-order serially correlated, a necessary condition for the consistency of the estimation. In all regressions, we can safely reject second order serial correlation.

${ }^{28}$ For predetermined variables such as initial income or initial secondary schooling, the first lag level is replaced by the second lag level.

${ }^{29}$ The results reported in the main tables are obtained with an instrument matrix that includes only the closest appropriate lags of the explanatory variables. The choice to restrict the instrument matrix is dictated by two considerations: (i) the Sargan test loses power when the set of instruments becomes large; (ii) if we used more instruments, we would run into a classical overfitting problem. 
to a potential endogeneity bias. First, we focus on identifying contrasting growth effects of exchange rate flexibility and volatility at different levels of financial development. Endogeneity will be less of an issue with an interaction term than with single variables. ${ }^{30}$ Second, we note that we obtain similar results for various measures of exchange rate volatility, as well as when we look at other measures of financial development (see below). Finally, by excluding high inflation "freely falling" exchange rate regimes in our baseline regressions, we are hopefully eliminating the most egregious cases where weak institutions would simultaneously explain low productivity growth and the choice of exchange rate regime (generally flexible because high inflation makes a sustained fix impossible).

The second avenue to evaluate the potential endogeneity problem is to rely on the existing literature that tries to explain exchange rate volatility or exchange rate regimes. The literature on exchange rate volatility is small, but it finds some robust determinants for the degree of volatility. For instance, Hau (2002) finds a negative correlation between real exchange rate volatility and trade openness. ${ }^{31}$ However, this does not affect our estimation as our specification includes both real exchange rate volatility and trade openness as regressors and treat them as jointly endogenous. Hausmann and al. (2004) investigate the determinants of real exchange rate volatility and find that GDP growth has a positive and statistically significant effect. This finding suggests that if a reverse causality link stems for growth to volatility, this link should be positive thus reinforcing our results.

The literature on the endogeneity of exchange rate regimes is more extensive, but it has been largely inconclusive. For instance, Juhn and Mauro (2002) apply the extreme bound method of Levine and Renelt (1992) on the effect of a large set of variables on the exchange rate regime and do not find any robust determinant. ${ }^{32}$ However, in a recent paper, Levy-Yeyati,

\footnotetext{
${ }^{30}$ Assume for instance that the choice of exchange rate regime coincides with the choice of other policies associated with higher future growth opportunities unaccounted for by the set of explanatory variables. This could directly bias the estimation of the effect of exchange flexibility in a linear regression set up. In contrast, this could bias the estimation of the interaction coefficient in our set-up only to the extent that the correlation between such policies and exchange rate flexibility or volatility varies significantly with the level of financial development.

${ }^{31}$ Bravo and di Giovanni (2005) have complemented this finding by showing that real exchange volatility is correlated with an index of remotness defined as weighed geographical distance from main trade centers. This correlation suggests that remotness can be a valid external instrument for real exchange volatility. However, remotness exhibits almost no time variation and thus is a weak instrument in our dynamic panel context. When we use remoteness as an external instrument in a pure cross-sectional estimation, our results broadly hold but with less significance.

${ }^{32}$ The findings of Juhn and Mauro (2002) have been obtained using Levy-Yeyati and Sturzenegger (2003) de facto classification and the IMF de jure classification. We applied the same methodology to the RR classification
} 
Sturzenegger, and Reggio (2004), using a logit analysis, find that some political variables can explain the likelihood of adopting a given exchange rate regime. We find that one of their political variables, VetoPoints, is a good instrument for exchange rate regimes. ${ }^{33}$ When we include this instrument in our GMM analysis, we find results similar to those of Table 1.

Beyond econometric tests, one can use the broad historical evidence to form a judgement on the endogeneity of exchange rate choices to future growth prospects. This is the approach followed by Eichengreen (1992) in his classical treatise. He shows that countries' choice to exit the inter-war gold standard had a huge impact on their subsequent growth trajectories. At the same time, the undisputed dogma in that period was that staying within the gold standard system was a necessary condition for economic recovery. A detailed discussion of the history of post-War exchange rate regimes falls outside the scope of this paper. However, our reading of the evidence compiled by Margaret De Vries (1985) and James Boughton (2001), in their massive sequential histories of the International Monetary Fund, is certainly consistent with politics, history and ideology playing a dominant role in most countries' choice of exchange rate or monetary policy regime. ${ }^{34}$ Indeed, although it is hard to deny that growth was always an objective of monetary policy, these histories make clear that there is a very large exogenous (for our purposes) component to exchange regime choice as well. ${ }^{35}$

\subsection{Robustness tests}

The set of regressions presented in Tables 1 to 4 offers solid evidence that the level of financial development plays an important role in mitigating the negative effects of exchange rate volatility on productivity growth. It is also reassuring that control variables in the regressions and found the same result. We would like to thank Paulo Mauro for sharing his methodology.

${ }^{33}$ We would like to thank Eduardo Levy-Yeyati for providing us the data. VetoPoints is an index measuring the extent of institutionalized constraints on the decision-making powers of chief executives. Notice that the non-political variables used in Levy-Yeyati et al. are already included in the set of our control variables.

${ }^{34}$ The dominant view of the IMF on exchange rate arrangement changed several time the last thirty years of the past century. In the early seventies, the IMF proposed to substitute to the failing Bretton Woods system, a system of fixed but adjustable exchange rate. Later in the decade, the conventional wisdom in the Fund became that the floating-rate regimes were working reasonably well. In the eighties, the Fund became gradually more favorable to fixed exchange rates regimes and their associated stabilizing and trade-promoting virtues. This position was later reversed in the nineties and the IMF started promoting exit strategies for countries seeking exchange rate flexibility (Eichengreen and al., 1998).

${ }^{35}$ Mussa (1986), especially, presents compelling evidence that the different behavior of real exchange rates under fixed versus floating regimes cannot possibly be attributed to exchange rate regime endogeneity (in part because the change typically occurs exactly on the day a country switches regimes even when the decision is announced long in advance.) 
have the expected effects: education and trade openness have a positive and often significant impact on growth while the effect of inflation and government burden is negative although not always statistically significant. Moreover, the results stay unchanged when the effects of crises are accounted for.

In this subsection, we discuss further evidence on the robustness of our main empirical findings. We examine whether the results are robust to different time periods, alternative exchange rate classifications, different measures of financial development and the omission of subgroups of countries. The main results corresponding to this discussion are presented in tables $\mathrm{A} 1$ to $\mathrm{A} 8$.

\subsubsection{Different time windows}

Using time effects in all our regressions, we control for any common factor that could affect all countries in any five-year interval. Moreover, our non-linear specification implicitly allows for time and cross-country variation in the effect of the flexibility of the exchange rate regime on productivity growth. However, we would like to check if our results hold when different time windows are used for the estimation. A sensitive issue is whether we should use any information from the period prior to the collapse of the Bretton-Woods system (1973). Our baseline time span is 1960-2000, but the early observations are used as internal instruments so that the first observation in levels that is actually considered in the estimation belongs to the 1970-1975 interval, while the first observation in difference is taken between the 1970-1975 and the 1965-1970 intervals. In Table A1, we are more restrictive and consider the information available only for the period 1970-2000 and in the period 1975-2000. In both cases, our main result holds. Moreover, the interaction coefficient is higher, indicating a stronger dependence of the effect of the flexibility of the exchange regime on the level of financial development. We also consider three successive periods of 20 years: 1960-1980; 1970-1990; 1980-2000. Our result holds significantly in the last two periods but not in the first, suggesting that our finding is actually stronger when we restrict our regression analysis to the post Bretton-Woods era. Performing the same robustness test on the effect of the interaction between financial development and real exchange rate volatility leads to the same conclusions. As shown in Table A2, the interaction effect is stronger when the information available is restricted to 1970-2000. 


\subsubsection{Alternative exchange rate regime classifications}

We have already examined the impact of three substantially different measures of exchange rate flexibility and obtained very similar results. However, it is useful to examine the results with other exchange rate classifications. Table A3 presents the robustness test to four alternative exchange rate classifications. In three out of four cases, our main result holds. First, our result is confirmed when the degree of exchange rate flexibility is measured on a more detailed scale using RR coarse classification (i.e., using 13 categories instead of the 4 used in the other tables). We notice that the implicit threshold above which a flexible exchange rate regime is growth enhancing is almost identical for the gross and coarse RR classifications. ${ }^{36}$ Second, the alternative de facto "consensus" classification of Gosh et al. (2003) yields similar results.

In contrast, when the classification of Levy-Yeyati and Sturzenegger (2003) (LYS) is used, the interaction with the level of financial development becomes negative but insignificant. In order to understand the differences between the results obtained with the RR and LYS classifications, we modify the latter in the following way: first, we eliminate the observations classified as free-falling by RR; second, we reclassify the observations with a dual exchange rate according to the $\mathrm{RR}$ classification. We then obtain a classification that combines the LYS clustering approach with the main innovations of RR. Interestingly, when this modified classification is used in the baseline regression, our main finding is confirmed. ${ }^{37}$ In that case, the point estimate of the interaction term is slightly higher than the point estimate of the interaction term in the regression using the $\mathrm{RR}$ classification on the same sample period (0.68 vs. 0.43$)$.

\subsubsection{Alternative measures of real exchange rate volatility}

We consider two alternative measures of exchange rate volatility: first, a measure of real effective exchange rate volatility computed with CPI indices and nominal exchange rates; second, a measure of nominal effective exchange rate volatility computed only with nominal exchange rates (see Appendix A for details). Table A4 reproduces the first two regressions presented in Table 2 over the full sample period and over a subsample period restricted to the post Bretton-Woods era.

When CPI-based real exchange volatility is introduced in the linear growth regression, it

\footnotetext{
${ }^{36} 55 \%$ vs $59 \%$ when the gross classification over 1970-2000 is considered (Table A1, col. 1)

${ }^{37}$ This seems to indicate that the LYS method tends to classify as fixed countries that are, de facto, more flexible through a dual exchange rate system, as well as countries that experience episodes of high inflation.
} 
exerts a negative and significant impact of productivity growth. The non-linear specification gives results very similar to our baseline estimation: the point estimate of the interaction term between exchange rate volatility and financial development is almost identical. The nonlinear specification using nominal effective exchange rate volatility delivers results similar to our baseline specification when the estimation is restricted to the post Bretton-Woods era. In that case, the magnitude of the interaction effect is close to the one obtained with real volatility (0.69 vs. 0.74). However, this result is not robust to the inclusion of the pre Bretton-Woods era: in that case, the interaction coefficient becomes small and insignificant. This result may not be surprising since nominal volatility was much lower under Bretton Woods.

\subsubsection{Alternative measures of financial development}

Table A5 shows the robustness of our main result to the use of alternative measures of financial development. Our initial and preferred measure is private credit to GDP from banks and other financial institutions. Our main result still holds when we consider the other side of the financial sector balance sheet (liquid liabilities over GDP) or when we restrict ourselves to a measure of the degree of financial intermediation provided by deposit money banks (deposit money banks assets over GDP).

\subsubsection{Alternative measure of economic development}

Instead of financial development we consider the distance to the technology frontier (represented by the US) expressed as:

$$
d_{i, t}=\ln \left(y_{i, t} / l_{i, t}\right)-\ln \left(y_{u s, t} / l_{u, t}\right)
$$

where $y_{i, t}$ and $l_{i, t}$ are the initial level of output and the labor force at the inception of each five year period. As our regressions include a common time effect, we can simply ignore the term $\ln \left(y_{u s, t} / l_{u, t}\right)$ and measure the distance to the frontier using the absolute level of labor productivity, $\ln \left(y_{i, t} / l_{i, t}\right)$.

As we are using the same baseline specification, the regressions without interacted terms are identical to the ones presented in columns 1 and 3 of Tables 1, 2, and 3. Notice that in the pure linear specification the coefficient on initial output per worker, i.e., the convergence term, is negative but not significant, except in the regression using real exchange rate volatility. Table A6 presents the results of regressions performed using the flexibility of exchange rate regime, real exchange rate volatility and real overvaluation. 
The three regressions shown in Table A6 show that the interaction between labor productivity and exchange rate flexibility has a positive and significant impact on growth. The interpretation is that the higher the level of productivity is, the better (or the less detrimental) is the impact of a more flexible exchange rate on productivity growth. We can identify a threshold level of output per worker above (below) which a more flexible (rigid) regime fosters productivity growth. For example, in the first column the point estimate of this threshold is US\$ 5000 (constant 1995 US\$), which is close to the current productivity levels of present-day Thailand and Peru and to the levels of Korea and Chile in the seventies.

\subsubsection{Omission of continents}

Table A7 and Table A8 show that our main result remains stable and significant when subgroups of countries are omitted in a systematic way. Our sample is partitioned into seven "continents" according to the World Bank classification. Then, the two baseline regressions (Regression [2], Table 1 and Regression [2], Table 2) are repeated with the omission of one continent at a time. The interaction term between exchange rate flexibility or volatility and financial development remains positive and significant at the 10 percent confidence level in thirteen out of fourteen regressions. ${ }^{38}$ Moreover, its point estimate is also stable and varies within a one standard error band around the corresponding benchmark point estimate.

\subsubsection{Crises and regime switching}

A typical scenario of a currency crisis is a period of a fixed exchange rate with growth followed, after a large devaluation, by a more flexible exchange rate and a depressed economy (e.g., the Asian, Mexican and Southern Cone crises). To determine whether this might be the driving force behind our results in Table 1, we made various tests. First, we introduced a crisis dummy in Table 1 and showed that this does not significantly affect our results. Second, we identified the cases in our sample where a switch from fixed to float was associated with a large decline in growth. We only found 6 episodes with a decline in growth larger than $5 \%$. Removing them from the sample does not affect the results of Table $1 .{ }^{39}$

\footnotetext{
${ }^{38}$ This result is especially remarkable considering that Windmejier (2004) correction for small sample is used in the estimation.

${ }^{39}$ These episodes are Chile \& Ecuador (81-82), Indonesia \& Thailand (97-98), Ghana (73-74) and Jamaica (90-91). The other episodes, such as Argentina in the early 1980s, are in the free falling category in RR and are not considered in our sample in Table 2.
} 


\subsubsection{Robustness against alternative non linear hypotheses}

We use an interaction term to test the hypothesis of a non linear growth effect of exchange rate flexibility or exchange rate volatility in the level of financial development. It is therefore important to distinguish our hypothesis from other alternative non-linear hypotheses. As a first robustness test, we add to our specification a quadratic term in exchange rate flexibility and a quadratic term in financial development. ${ }^{40}$ Our main result changes very little in this specification. A second robustness test is performed using the following procedure: ${ }^{41}$ (i) first we regress exchange rate flexibility on the other regressors and obtain a flexibility residual; (ii) second, we regress financial development on the other regressors and obtain a financial development residual; (iii) we perform our baseline estimation replacing the interaction term by the interaction of the computed residuals. By this method, we exclude the possibility that our result is influenced by other interaction effects between financial development or exchange rate flexibility and the rest of the explanatory variables. ${ }^{42}$ In this specification, the interaction effect between exchange rate flexibility and growth remains significant. Its point estimate is indeed slightly larger suggesting that if anything, the baseline specification tends to underestimate the magnitude of the interaction effect.

\section{Conclusion}

The vast empirical literature following Baxter-Stockman (1989) and Flood-Rose (1994) generally finds no detectable difference in macroeconomic performance between fixed and floating exchange rate regimes. In this paper, we argue that instead of looking at exchange rate volatility in isolation, it is important to look at the interaction between the exchange rate volatility and both the level of financial development and the nature of macroeconomic shocks. We develop a theoretical model in which higher levels of exchange rate volatility can stunt growth, especially in countries with thin capital markets and where financial shocks are the main source of macroeconomic volatility. Our predictions are then shown to be largely validated by cross-country panel data, which thus provide fairly robust evidence suggesting the importance of the financial development for how the choice of exchange rate regime affects growth. ${ }^{43}$

\footnotetext{
${ }^{40}$ The idea of the test is that if financial development is correlated with exchange rate flexibility, the interaction term can capture a quadratic effect in financial development or in exchange rate flexibility.

${ }^{41}$ We are grateful to Ben Sorensen for having suggested this robustness test.

${ }^{42}$ We also exclude once more the hypothesis of a quadratic effect in financial development or exchange rate flexibility

${ }^{43}$ Rogoff et. al (2004) and Husain, Mody and Rogoff (2005) do find differences in exchange rate regime performance across developing countries, emerging markets and advanced economies. However, perhaps because
} 
Are our result at odds with the prescriptions of the standard exchange rate models? Not necessarily. The classical literature holds that the greater the volatility of real shocks relative to financial shocks a country faces, the more flexibility it should allow in its exchange rate. Our analysis shows that this prescription has to be modified to allow for the fact that financial market shocks are amplified in developing countries with thin and poorly developed credit markets. Clearly, more fully articulated structural models are needed to properly measure the tradeoffs, and this would appear to be an important challenge for future research.

they do not incorporate any structural variables in their regressions such as private credit to GDP, or distance to frontier, they only found significant and robust effects of exchange rate regime choice on growth in advanced economies. 


\section{References}

[1] Aghion, Ph., G.M. Angeletos, A. Banerjee, and K. Manova (2005), "Volatility and Growth: Financial Development and the Cyclical Behavior of the Composition of Investment," mimeo.

[2] Aghion, Ph., Ph. Bacchetta, and A. Banerjee (2004), "A Corporate Balance-Sheet Approach to Currency Crises," Journal of Economic Theory 119, 6-30.

[3] Aghion, Ph., P. Howitt, and D. Mayer-Foulkes (2005), "The Effect of Financial Development on Convergence: Theory and Evidence," Quarterly Journal of Economics 120(1), 173-222.

[4] Arellano M. and S. Bond (1991), "Some Tests of Specification for Panel Data: Monte Carlo Evidence and an Application to Employment Equations," Review of Economic Studies, 58, 277-297.

[5] Arellano M. and O. Bover (1995), "Another Look at the Instrumental-Variable Estimation of Error-Components Models," Journal of Econometrics 68, 29-51.

[6] Bacchetta, Philippe and van Wincoop, Eric (2000), "Does Exchange Rate Stability Increase Trade and Welfare?," American Economic Review 90, 1093-1109.

[7] Bacchetta, Philippe and Eric van Wincoop (2006), "Can Information Heterogeneity Explain the Exchange Rate Determination Puzzle?," American Economic Review, forthcoming.

[8] Baldwin, Richard (1989) "Growth Effects of 1992," Economic Policy, 9, 247-282.

[9] Baum Christopher, Mark E. Schaffer and Steven Stillman, 2003, "Instrumental variables and GMM: Estimation and testing," Stata Journal, 3(1):1-31.

[10] Baxter, Marianne and Alan Stockman (1989), "Business Cycles and the Exchange-Rate Regime," Journal of Monetary Economics 23(3), 377-400.

[11] Blundell R., and S. Bond (1998), "Initial conditions and Moment Conditions in Dynamic Panel Data Models," Journal of Econometrics, 87, 115-143.

[12] Bond, S. (2002), "Dynamic Panel Data Models: A Guide to Micro Data Methods and Practice," cemmap working paper no. 09/02. 
[13] Boughton, James (2001), Silent Revolution, The International Monetary Fund, 1979-1989, International Monetary Fund

[14] Bravo-Ortega Claudio and Julian di Giovanni (2005), "Remoteness and Real Exchange Rate Volatility," IMF Working Paper No. 05/01

[15] Broda, Christian (2004), "Terms of Trade and Exchange Rate Regimes in Developing Countries," Journal of International Economics 63, 31-58.

[16] Calvo, G.A. and C. M. Reinhart (2002), "Fear of Floating," Quarterly Journal of Economics $117,379-408$.

[17] Clark, P., N. Tamirisa, and Shang-Jin Wei (2004), "A New Look at Exchange Rate Volatility and Trade Flows," IMF Occasional Paper No. 235.

[18] De Grauwe, P. and G. Schnabl (2005), "Exchange Rate Stability, Inflation and Growth in (South) Eastern and Central Europe," mimeo.

[19] Devereux, M.B. and P.R. Lane (2003), "Understanding Bilateral Exchange Rate Volatility," Journal of International Economics 60, 109-132.

[20] Dollar D. (1992), "Outward Oriented Economies Really Do Grow More Rapidly: Evidence from 95 LDCs, 1976-1985," Economic Development and Cultural Change, 940-3, 523-544.

[21] Duarte, M. and A.C. Stockman (2005), "Rational Speculation and Exchange Rates," Journal of Monetary Economics 52, 3-29.

[22] Dubas, J.M., B.-J. Lee, and N.C. Mark (2005), "Effective Exchange Rate Classifications and Growth," NBER Working Papers 11272.

[23] Eichengreen Barry (1992), Golden Fetters: The Gold Standard and the Great Depression,1919-1939,.Oxford University Press

[24] Eichengreen, Barry J., Johnston, R. B, Masson, Paul R, Jadresic, Esteban and Bredenkamp, Hugh Hamann, A. Javier and Inci Ötker (1998), "Exit Strategies: Policy Options for Countries Seeking Exchange Rate Flexibility," IMF Occasional Paper No. 168

[25] Edwards, Sebastian, and Eduardo Levy Yeyati (2005), "Flexible Exchange Rates as Shock Absorbers," European Economic Review 49(8), 2079-2105. 
[26] Engel, C. and M. Devereux (2002), "Exchange Rate Pass-Through, Exchange Rate Volatility, and Exchange Rate Disconnect," Journal of Monetary Economics, June 2002, 913-940.

[27] Frankel, J. and A. Rose (2002), "An Estimate of the Effect of Common Currencies on Trade and Income," Quarterly Journal of Economics May, 437-468.

[28] Garber, Peter M., and Lars E.O. Svensson (1995), "The Operation and Collapse of Fixed Exchange Rate Regimes “ in Gene M. Grossman and Kenneth Rogoff (eds.), The Handbook of International Economics, vol. 3, (Amsterdam, Elsevier Press).

[29] Ghosh, A., A.M. Gulde, and H.C. Wolf (2003), Exchange Rate Regimes: Choices and Consequences, MIT Press.

[30] Goldfajn, I. and R.Valdes (1999), "The Aftermath of Appreciations," Quarterly Journal of Economics 114, 229-62

[31] Hau, Harald (2002), "Real Exchange Rate Volatility and Economic Openness: Theory and Evidence," Journal of Money, Credit and Banking 34(3), 611-630.

[32] Hausmann, R., U. Panizza, and R. Rigobon (2004), "The Long-Run Volatility Puzzle of the Real Exchange Rate," NBER Working Paper No. 10751.

[33] Huang, H. and P. Malhotra (2004), "Exchange Rate Regimes and Economic Growth: Evidence from Developing Asian and Advanced European Economies," mimeo, IMF.

[34] Husain, A. M., A. Mody, and K.S. Rogoff (2005), "Exchange Rate Regime Durability and Performance in Developing versus Advanced Economies," Journal of Monetary Economics 52, 35-64.

[35] Jeanne, O. and A.K. Rose (2002), "Noise Trading and Exchange Rate Regimes," Quarterly Journal of Economics 117, May, 537-69.

[36] Juhn, Grace and Mauro, Paolo (2002), "Long-Run Determinants of Exchange Rate Regimes: A Simple Sensitivity Analysis," IMF Working Papers 02/104.

[37] Kollman, Robert (2002), "Monetary Policy Rules in the Open Economy: Effects on Welfare and Business Cycles," Journal of Monetary Economics 49, 989-1015.

[38] Krugman, Paul (1987), The Age of Diminished Expectations, MIT Press. 
[39] Levine, R., Loayza N. and T. Beck (2000), "Financial Intermediation and Growth: Causality and Causes," Journal of Monetary Economics, 46(1), 31-77.

[40] Levine, Ross and Renelt, David (1992), "A Sensitivity Analysis of Cross-Country Growth Regressions," American Economic Review, 82(4), 942-63.

[41] Loayza, N. and R. Ranciere (2005), "Financial Development, Financial Fragility and Growth", Journal of Money, Credit and Banking, forthcoming

[42] Levy-Yeyati, E. and F. Sturzenegger (2003), "To Float or to Fix: Evidence on the Impact of Exchange Rate Regimes on Growth," American Economic Review 93, 1173-1193.

[43] Levy-Yeyati, E., F. Sturzenegger and I. Reggio (2004), "On the Endogeneity of Exchange Rate Regimes," mimeo.

[44] Mussa, Michael (1986), "Nominal Exchange Rate Regimes and the Behavior of Real Exchange Rates: Evidence and Implications," Carnegie-Rochester Series on Public Policy, 25:117-214.

[45] Mendoza Enrique (1997), "Terms-of-trade uncertainty and economic growth," Journal of Development Economics, 54(2), 323-356.

[46] Obstfeld, M. (2004), "Pricing-to-Market, the Interest-Rate Rule, and the Exchange Rate," mimeo.

[47] Obstfeld, Maurice and Kenneth Rogoff (1996), Foundations of International Macroeconomics, MIT Press.

[48] Obstfeld, Maurice and Kenneth Rogoff (2000), "The Six Major Puzzles in International Macroeconomics: Is There a Common Cause?" NBER Macroeconomics Annual 15.

[49] Razin, A. and Y. Rubinstein (2004), "Growth Effects of the Exchange-Rate Regime and the Capital-Account Openness in A Crisis-Prone World Market: A Nuanced View," NBER WP No. 10555.

[50] Reinhart, C.M. and K.S. Rogoff (2004), "The Modern History of Exchange Rate Arrangements: A Reinterpretation," Quarterly Journal of Economics 119(1):1-48, February.

[51] Rogoff, Kenneth, Aasim M. Husain, Ashoka Mody, Robin J. Brooks, and Nienke Oomes (2004), "Evolution and Performance of Exchange Rates Regimes", International Monetary Fund Occasional Paper No. 229. 
[52] Rose, A. (2000), "One Money, One Market: Estimating the Effect of Common Currencies on Trade," Economic Policy 30, 7-46.

[53] Shambaugh, J.C. (2004), "The Effect of Fixed Exchange Rates on Monetary Policy," Quarterly Journal of Economics 119, 301-352.

[54] Windmeijer, F., (2004), "A finite sample correction for the variance of linear two-step GMM estimator," Journal of Econometrics, 126-1, 25-51

[55] Woodford, M. (2003), Interest and Prices: Foundations of a Theory of Monetary Policy, Princeton University Press. 
Figure 1: Real Exchange Rate Volatility, Exchange Rate Flexibility and Productivity Growth
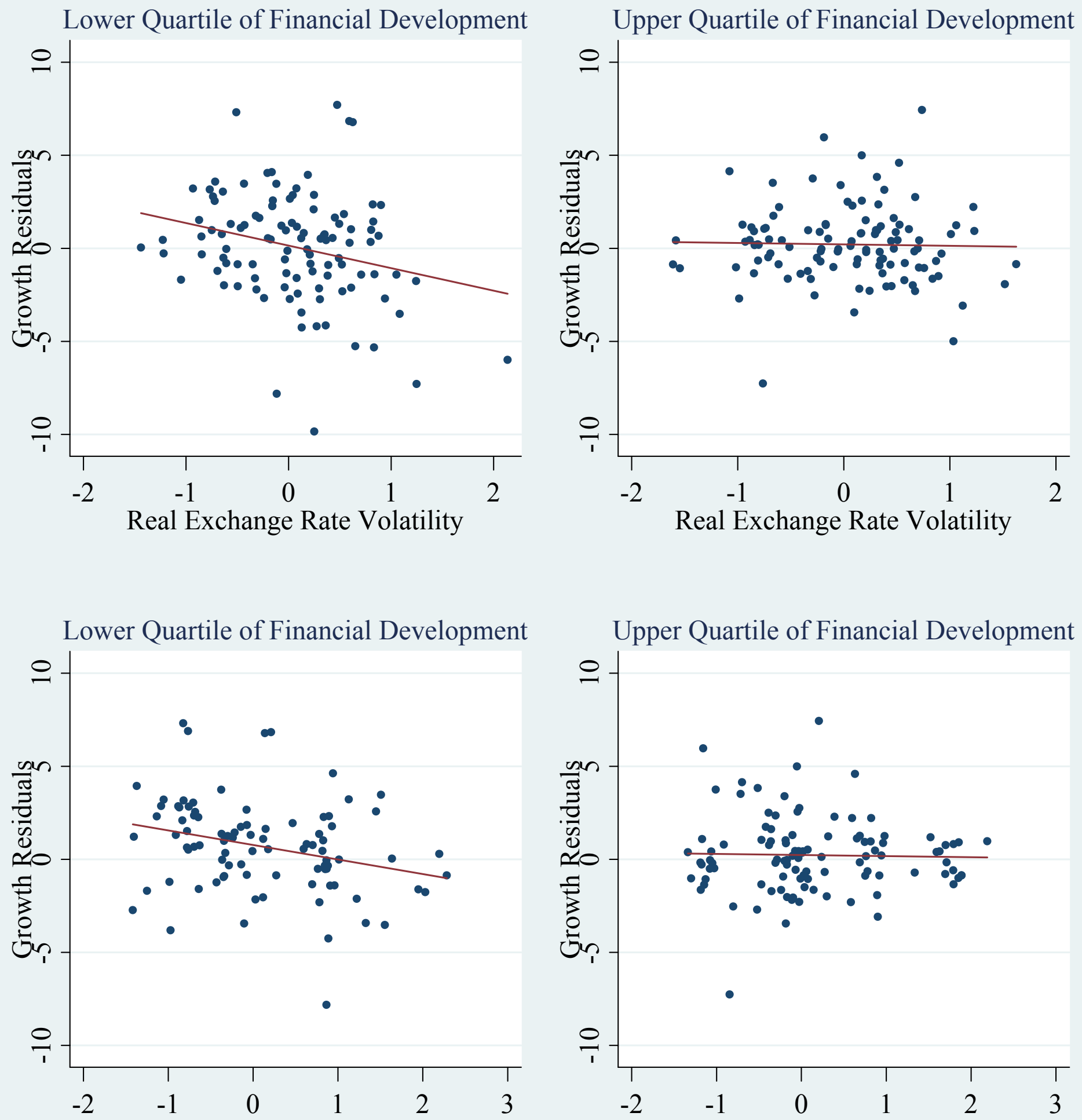

Flexibility of Exchange Rate Regime

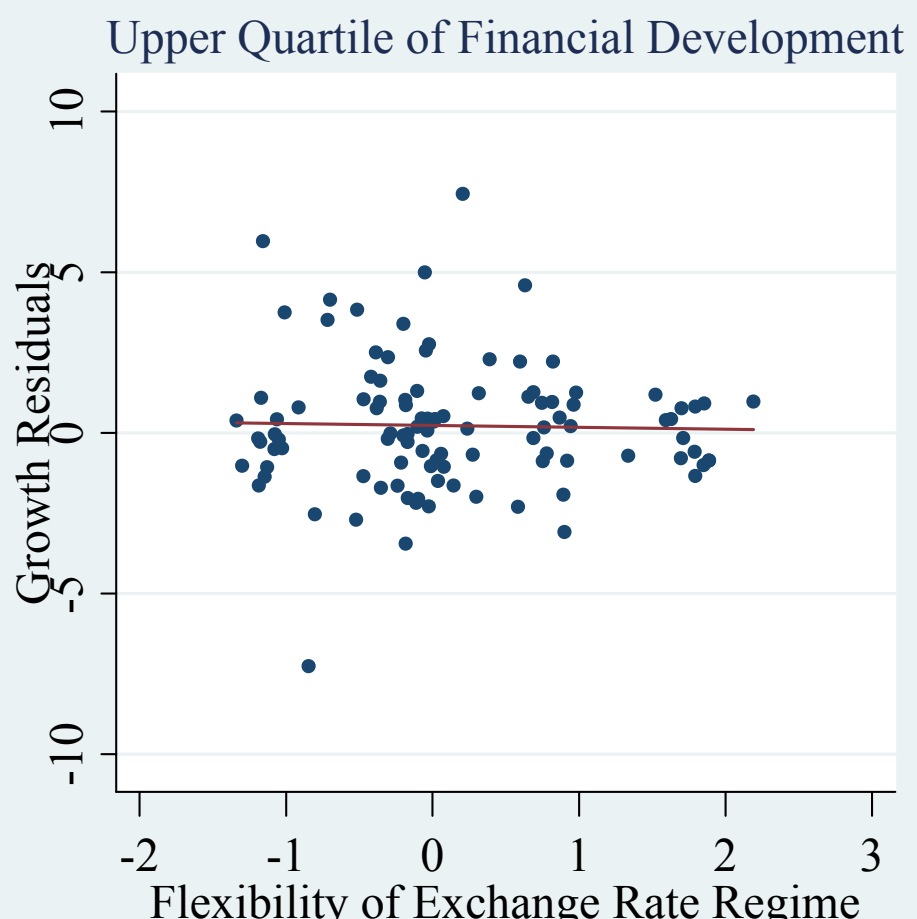


Table 1

Growth Effects of the Flexibility of Exchange Rate Regime

Dependent Variable: Growth Rate of Output per Worker

Estimation: 2-step system GMM estimation with Windmeijer (2004) Small Sample Robust Correction and Time Effects

(Standard errors are presented below the corresponding coefficient)

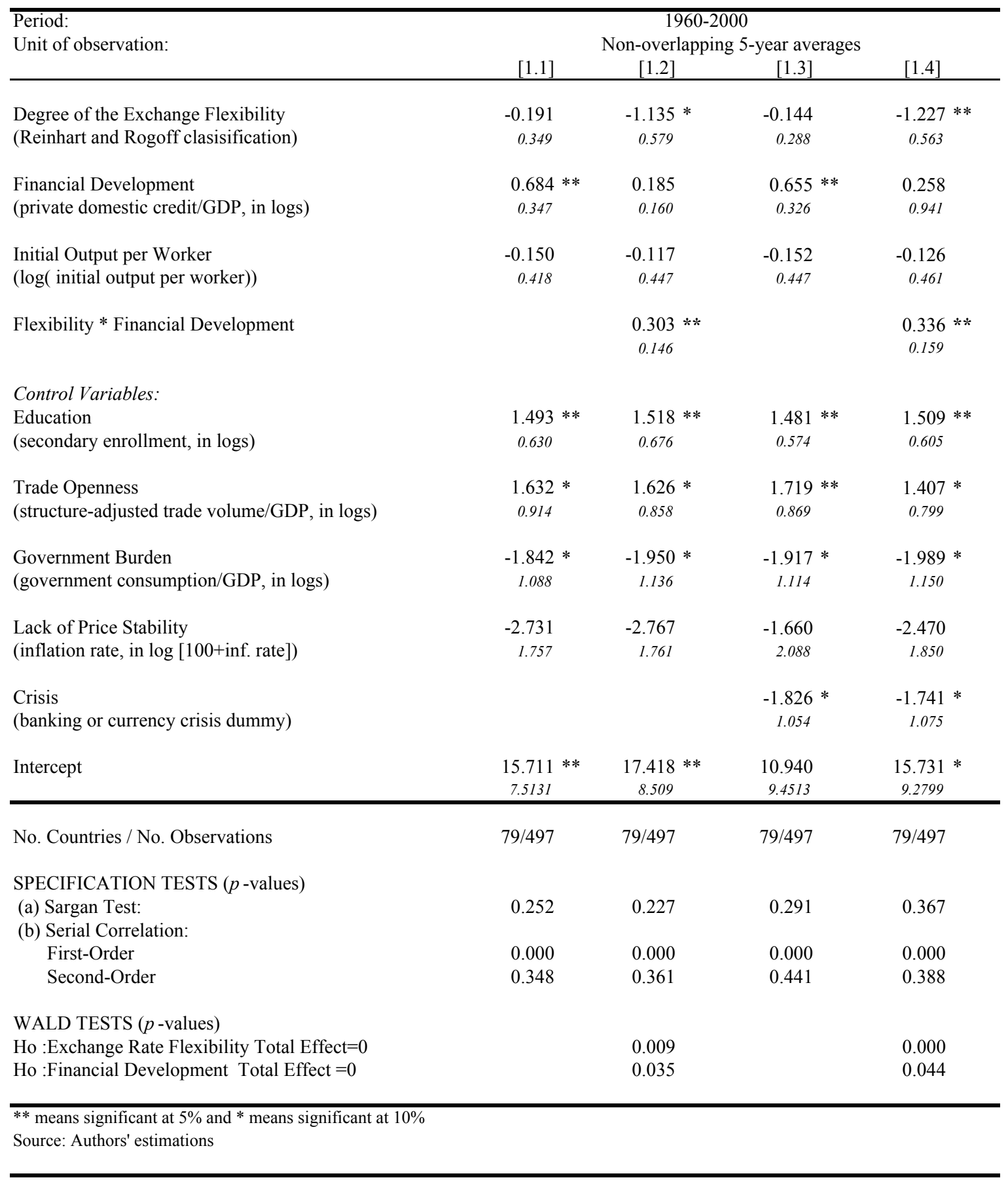

\section{THRESHOLD ANALYSIS}

Growth enhancing effect of exchange rate flexibility:

$\begin{array}{lll}\text { Private Credit /GDP greater than: } & 0.424 & 0.385\end{array}$

s.e.

$0.190 \quad 0.170$


Table 2

Growth Effects of Real Effective Exchange Rate Volatility

Dependent Variable: Growth Rate of Output per Worker

Estimation: 2-step system GMM estimation with Windmeijer (2004) Small Sample Robust Correction and Time Effects

(Standard errors are presented below the corresponding coefficient)

\section{Period:}

Unit of observation:

Real Exchange Rate Volatility

Financial Development

(private domestic credit/GDP, in logs)

Initial Output per Worker

$(\log ($ initial output per worker $))$

Exchange Rate Volatility * Financial Development

Control Variables:

Education

(secondary enrollment, in logs)

Trade Openness

(structure-adjusted trade volume/GDP, in logs)

Government Burden

(government consumption/GDP, in logs)

Lack of Price Stability

(inflation rate, in $\log [100+$ inf. rate])

Crisis

(banking or currency crisis dummy)

Intercept

No. Countries / No. Observations

SPECIFICATION TESTS ( $p$-values)

(a) Sargan Test:

(b) Serial Correlation :

First-Order

Second-Order

WALD TESTS ( $p$-values)

Ho :Exchange Rate Flexibility Total Effect $=0$

Ho :Financial Development Total Effect $=0$

1960-2000

Non-overlapping 5-year averages

$\begin{array}{cccc}{[2.1]} & {[2.2]} & {[2.3]} & {[2.4]} \\ -0.637 * * & -3.124 * * & -0.554 * * & -3.319 * * \\ 0.273 & 1.204 & 0.262 & 1.208 \\ & & & \\ 1.111 * * & -0.650 & 0.987 * * & -0.729 \\ 0.455 & 0.808 & 0.402 & 0.821 \\ & & & \\ -1.112 * * & -0.530 & -1.025 * * & -0.828 * * \\ 0.391 & 0.474 & 0.360 & 0.404 \\ & & & 0.706 * * \\ & 0.677 * * & & 0.277\end{array}$

$\begin{array}{rccc}1.807 * * & 1.778 * * & 1.976 * * & 2.378 * * \\ 0.532 & 0.694 & 0.465 & 0.585 \\ & & & \\ & & & \\ 1.053 * & 1.115 * * & 1.420 * * & 1.579 * \\ 0.572 & 0.769 & 0.569 & 0.975 \\ & & & \\ -0.416 & -0.928 & -1.068 & -0.871 \\ 1.153 & 1.070 & 1.104 & 1.372\end{array}$

$\begin{array}{llll}-2.569 * & -1.961 & -1.872 * & -1.172\end{array}$

$\begin{array}{llll}1.487 & 1.237 & 1.117 & 1.379\end{array}$

$-2.250 * * \quad-2.857 * *$

$0.878 \quad 1.374$

$8.325^{* *} \quad 13.346^{* *} \quad 15.689 * * \quad 14.556 * *$

7.043

5.072
6.971

$\begin{array}{llll}83 / 548 & 83 / 548 & 83 / 548 & 83 / 548\end{array}$

$\begin{array}{llll}0.461 & 0.241 & 0.663 & 0.187 \\ 0.000 & 0.000 & 0.000 & 0.000 \\ 0.462 & 0.383 & 0.572 & 0.516\end{array}$

0.000

0.000

0.032

** means significant at $5 \%$ and * means significant at $10 \%$

Source: Authors' estimations

THRESHOLD ANALYSIS

Growth enhancing effect of exchange rate flexibility if:

Private Credit /GDP greater than:

s.e

$\begin{array}{rr}1.01 & 1.10 \\ 0.34 & 0.39\end{array}$


Table 3

Growth Effects of Effective Exchange Rate Real Overvaluation

Dependent Variable: Growth Rate of Output per Worker

Estimation: 2-step system GMM estimation with Windmeijer (2004) Small Sample Robust Correction and Time Effects (Standard errors are presented below the corresponding coefficient)

Period:

Unit of observation:
1960-2000

\begin{tabular}{|c|c|c|c|c|}
\hline & [3.1] & {$[3.2]$} & {$[3.3]$} & {$[3.4]$} \\
\hline $\begin{array}{l}\text { Degree of the Real Exchange Rate Overvaluation } \\
\text { (log deviation from equilibrium exchange rate) }\end{array}$ & $\begin{array}{l}-0.995 * * \\
0.504\end{array}$ & $\begin{array}{c}-1.162 * \\
0.711\end{array}$ & $\begin{array}{l}-1.176 * * \\
0.534\end{array}$ & $\begin{array}{l}-1.179 * * \\
0.659\end{array}$ \\
\hline $\begin{array}{l}\text { Financial Development } \\
\text { (private domestic credit/GDP, in logs) }\end{array}$ & $\begin{array}{l}0.636 * \\
0.345\end{array}$ & $\begin{array}{r}-0.101 \\
2.509\end{array}$ & $\begin{array}{l}0.595 * \\
0.330\end{array}$ & $\begin{array}{r}-0.040 \\
2.163\end{array}$ \\
\hline $\begin{array}{l}\text { Initial Output per Worker } \\
(\log (\text { initial output per worker }))\end{array}$ & $\begin{array}{r}-0.038 \\
0.382\end{array}$ & $\begin{array}{r}-0.360 \\
0.531\end{array}$ & $\begin{array}{r}-0.057 \\
0.369\end{array}$ & $\begin{array}{r}-0.355 \\
0.518\end{array}$ \\
\hline Real overvaluation * Financial Development & & $\begin{array}{l}0.205 * * \\
0.077\end{array}$ & & $\begin{array}{l}0.163 * * \\
0.082\end{array}$ \\
\hline $\begin{array}{l}\text { Control Variables: } \\
\text { Education } \\
\text { (secondary enrollment, in logs) }\end{array}$ & $\begin{array}{l}1.185 * \\
0.613\end{array}$ & $\begin{array}{l}1.532 * * \\
0.772\end{array}$ & $\begin{array}{l}1.245 * * \\
0.595\end{array}$ & $\begin{array}{l}1.645^{* *} \\
0.800\end{array}$ \\
\hline $\begin{array}{l}\text { Trade Openness } \\
\text { (structure-adjusted trade volume/GDP, in logs) }\end{array}$ & $\begin{array}{l}1.328 * * \\
0.626\end{array}$ & $\begin{array}{l}1.619^{* *} \\
0.688\end{array}$ & $\begin{array}{l}1.462 * \\
0.812\end{array}$ & $\begin{array}{l}1.630 * * \\
0.777\end{array}$ \\
\hline $\begin{array}{l}\text { Government Burden } \\
\text { (government consumption/GDP, in logs) }\end{array}$ & $\begin{array}{c}-1.457 * \\
0.827\end{array}$ & $\begin{array}{r}-2.184 \\
1.358\end{array}$ & $\begin{array}{r}-1.329 \\
0.875\end{array}$ & $\begin{array}{r}-1.931 \\
1.483\end{array}$ \\
\hline $\begin{array}{l}\text { Lack of Price Stability } \\
\text { (inflation rate, in } \log [100+\text { inf. rate }] \text { ) }\end{array}$ & $\begin{array}{l}-4.505^{* *} \\
1.009\end{array}$ & $\begin{array}{l}-3.819^{* *} \\
1.160\end{array}$ & $\begin{array}{l}-3.857 * * \\
0.935\end{array}$ & $\begin{array}{l}-3.708 * * \\
0.881\end{array}$ \\
\hline $\begin{array}{l}\text { Crisis } \\
\text { (banking or currency crisis dummy) }\end{array}$ & & & $\begin{array}{r}-1.281 \\
1.326\end{array}$ & $\begin{array}{r}-2.082 \\
1.284\end{array}$ \\
\hline Intercept & $\begin{array}{c}27.612 \\
5.720\end{array}$ & $\begin{array}{l}27.551 * * \\
8.751\end{array}$ & $\begin{array}{l}25.148 \text { ** } \\
5.556\end{array}$ & $\begin{array}{l}26.882 * * \\
7.626\end{array}$ \\
\hline No. Countries / No. Observations & $83 / 548$ & $83 / 548$ & $83 / 548$ & $83 / 548$ \\
\hline $\begin{array}{l}\text { SPECIFICATION TESTS ( } p \text {-values) } \\
\text { (a) Sargan Test: } \\
\text { (b) Serial Correlation : } \\
\text { First-Order } \\
\text { Second-Order }\end{array}$ & $\begin{array}{l}0.000 \\
0.268\end{array}$ & $\begin{array}{l}0.000 \\
0.278\end{array}$ & $\begin{array}{l}0.279 \\
0.000 \\
0.359\end{array}$ & $\begin{array}{l}0.220 \\
0.000 \\
0.271\end{array}$ \\
\hline $\begin{array}{l}\text { WALD TESTS ( } p \text {-values) } \\
\text { Ho :Exchange Rate Flexibility Total Effect }=0 \\
\text { Ho :Financial Development Total Effect }=0\end{array}$ & & $\begin{array}{l}0.000 \\
0.037\end{array}$ & & $\begin{array}{l}0.000 \\
0.028\end{array}$ \\
\hline
\end{tabular}

THRESHOLD ANALYSIS

Growth enhancing effect overvaluation:

$\begin{array}{lll}\text { Private Credit /GDP greater than: } & 1.63 & 1.28\end{array}$

s.e.

1.28
0.65
0.48


Table 4

Growth Effects of the Flexibility of Exchange Rate Regime,Terms-of-Trade Growth and Volatility

Dependent Variable: Growth Rate of Output per Worker

Estimation: 2-step system GMM estimation with Windmeijer (2004) Small Sample Robust Correction and Time Effects

(Standard errors are presented below the corresponding coefficient)

Period:

Unit of observation:

$[4.1]$

Terms-of-Trade Growth

Terms-of-Trade Volatility

Degree of the Exchange Flexibility

(Reinhart and Rogoff classification)

Financial Development

(private domestic credit/GDP, in logs)

Initial Output per Worker

$(\log ($ initial output per worker $))$

Flexibility *Terms-of-Trade Growth

Flexibility *Terms-of-Trade Volatility

Flexibility*Financial Development

Control Variables:

Education

(secondary enrollment, in logs)

Trade Openness

(structure-adjusted trade volume/GDP, in logs)

Government Burden

(government consumption/GDP, in logs)

Lack of Price Stability

(inflation rate, in $\log [100+$ inf. rate $]$ )

Intercept

No. Countries / No. Observations

SPECIFICATION TESTS ( $p$-values)

(a) Sargan Test:

(b) Serial Correlation :

First-Order

Second-Order

** means significant at $5 \%$ and * means significant at $10 \%$

Source: Authors' estimations

1960-2000

Non-overlapping 5-year averages

$[4.2] \quad[4.3] \quad[4.4]$

$0.385 * *$

0.173

$\begin{array}{ccc}0.092 * & 0.327 * & 0.385 \\ 0.054 & 0.169 & 0.173\end{array}$

$\begin{array}{ccc} & & \\ & & \\ & -0.068 & -0.826 \\ & 1.226 & 0.658 \\ 1.039 * * & 0.783 * & 0.285 \\ 0.463 & 0.395 & 0.192 \\ -0.526 & -0.644 * & -0.702 \\ 0.460 & 0.381 & 0.465 \\ & & \\ & -0.107 * * & -0.136 * * \\ & 0.044 & 0.062\end{array}$

$-0.205 *$

$-1.189 * *$

0.113

0.421

0.410

$-0.853 * * \quad-2.748 * *$

$0.392 \quad 1.179$

$0.681 * \quad 0.722 * \quad-1.178$

$\begin{array}{lll}0.378 & 0.411 & 0.755\end{array}$

$\begin{array}{lll}-0.396 & -0.173 & -0.061\end{array}$

$\begin{array}{lll}0.404 & 0.455 & 0.514\end{array}$

$0.394 * * \quad 0.476 * *$

$0.357 * *$

$0.525 *$

0.159

0.283

\begin{tabular}{|c|c|c|c|c|c|}
\hline $1.740 * *$ & $2.301 * *$ & $2.301 * *$ & $1.541 * *$ & $1.457 * *$ & $1.166 *$ \\
\hline 0.517 & 0.467 & 0.571 & 0.529 & 0.642 & 0.687 \\
\hline 0.652 & 1.493 & $1.385 *$ & 1.339 & $1.734 * *$ & $1.832 * *$ \\
\hline 0.746 & 1.074 & 0.706 & 0.962 & 0.878 & 0.931 \\
\hline-0.770 & -0.762 & -0.707 & -0.136 & -0.977 & -0.810 \\
\hline 1.248 & 1.191 & 0.982 & [1.049] & 0.930 & 0.930 \\
\hline$-2.620 * *$ & $-4.354 * *$ & $-3.560 * *$ & $-2.805 *$ & $-1.997 *$ & $-1.900 *$ \\
\hline 1.260 & 1.784 & 1.432 & 1.567 & 0.989 & 1.020 \\
\hline $13.700 * *$ & $20.450 * *$ & $20.000 * *$ & 13.886 & 13.388 & 17.756 \\
\hline 6.310 & 12.850 & 9.815 & 7.358 & 14.469 & 15.327 \\
\hline $83 / 548$ & $79 / 494$ & $79 / 494$ & $83 / 548$ & $79 / 494$ & $79 / 494$ \\
\hline 0.335 & 0.420 & 0.680 & 0.670 & 0.840 & 0.830 \\
\hline 0.000 & 0.000 & 0.000 & 0.000 & 0.000 & 0.000 \\
\hline 0.499 & 0.450 & 0.450 & 0.610 & 0.510 & 0.480 \\
\hline
\end{tabular}


Table A 1

Growth Effects of the Flexibility of Exchange Rate Regime

Robustness: Different Time Windows

Dependent Variable: Growth Rate of Output per Worker

Estimation: 2-step system GMM estimation with Windmeijer (2004) Small Sample Robust Correction and Time Effects

(Standard errors are presented below the corresponding coefficient)

\begin{tabular}{|c|c|c|c|c|c|c|}
\hline \multirow{3}{*}{$\begin{array}{l}\text { Period: } \\
\text { Unit of observation: }\end{array}$} & $1970-2000$ & $1975-2000$ & $1960-1980$ & $1970-1990$ & & $1980-2000$ \\
\hline & \multicolumn{6}{|c|}{ Non-overlapping 5 -year averages } \\
\hline & [1] & [2] & [3] & [4] & & [5] \\
\hline Degree of the Exchange Flexibility & $-1.742 * *$ & $-3.090 * *$ & -1.189 & -2.381 & * & $-3.366 * *$ \\
\hline (Reinhart and Rogoff clasisification) & 0.745 & 1.453 & 2.010 & 1.126 & & 1.540 \\
\hline Financial Development & -0.800 & -2.055 & 0.080 & -2.040 & & -2.110 \\
\hline (private domestic credit/GDP, in logs) & 0.666 & 1.455 & 0.126 & 1.280 & & 1.550 \\
\hline Initial Output per Worker & 0.132 & 0.102 & 0.002 & 0.240 & & 0.698 \\
\hline (log( initial output per worker)) & 0.378 & 0.540 & 0.371 & 0.480 & & 0.540 \\
\hline \multirow[t]{2}{*}{ Flexibility * Financial Development } & $0.428 * *$ & $0.751 * *$ & 0.330 & 0.493 & * & $0.749 * *$ \\
\hline & 0.229 & 0.321 & 0.340 & 0.274 & & 0.353 \\
\hline No. Countries / No. Observations & $79 / 421$ & $79 / 352$ & $78 / 273$ & $78 / 275$ & & $79 / 282$ \\
\hline \multicolumn{7}{|l|}{ SPECIFICATION TESTS ( $p$-values) } \\
\hline (a) Sargan Test: & 0.596 & 0.269 & 0.279 & 0.162 & & 0.155 \\
\hline (b) Second Order Serial Correlation : & 0.125 & 0.619 & 0.153 & 0.269 & & 0.47 \\
\hline
\end{tabular}

Table A 2

Growth Effects of the Real Effective Exchange Rate Volatility

Robustness: Different Time Windows

Dependent Variable: Growth Rate of Output per Worker

Estimation: 2-step system GMM estimation with Windmeijer (2004) Small Sample Robust Correction and Time Effects

(Standard errors are presented below the corresponding coefficient)

\begin{tabular}{|c|c|c|c|c|c|}
\hline \multirow{2}{*}{$\begin{array}{l}\text { Period: } \\
\text { Unit of observation: }\end{array}$} & $1970-2000$ & $1975-2000$ & $1960-1980$ & $1970-1990$ & $1980-2000$ \\
\hline & [1] & $\begin{array}{l}\text { Non-overla } \\
{[2]}\end{array}$ & & \multicolumn{2}{|c|}{ Non-overlapping 5-year averages } \\
\hline Real Exchange Rate Volatility & $\begin{array}{l}-4.002 * * \\
0.464\end{array}$ & $\begin{array}{c}-4.493 * * \\
1.587\end{array}$ & $\begin{array}{r}-3.561 \\
2.720\end{array}$ & $\begin{array}{c}-5.231 * * \\
1.630\end{array}$ & $\begin{array}{c}-3.934 * * \\
1.326\end{array}$ \\
\hline $\begin{array}{l}\text { Financial Development } \\
\text { (private domestic credit/GDP, in logs) }\end{array}$ & $\begin{array}{r}-1.747 \\
1.159\end{array}$ & $\begin{array}{l}-2.566 * \\
1.373\end{array}$ & $\begin{array}{r}-1.064 \\
2.396\end{array}$ & $\begin{array}{l}-3.325 * * \\
1.265\end{array}$ & $\begin{array}{l}-2.501 * * \\
1.149\end{array}$ \\
\hline $\begin{array}{l}\text { Initial Output per Worker } \\
(\log (\text { initial output per worker }))\end{array}$ & $\begin{array}{r}-0.374 \\
0.474\end{array}$ & $\begin{array}{l}1.009 * \\
0.606\end{array}$ & $\begin{array}{r}-0.949 \\
0.855\end{array}$ & $\begin{array}{r}0.486 \\
0.522\end{array}$ & $\begin{array}{r}0.928 \\
0.664\end{array}$ \\
\hline Exchange Rate Volatility * Financial Development & $\begin{array}{l}1.030 * * \\
0.464\end{array}$ & $\begin{array}{l}1.077 * * \\
0.464\end{array}$ & $\begin{array}{r}0.716 \\
0.464\end{array}$ & $\begin{array}{l}1.249 * * \\
0.412\end{array}$ & $\begin{array}{l}0.939 * * \\
0.401\end{array}$ \\
\hline No. Countries / No. Observations & $83 / 475$ & $83 / 398$ & $83 / 307$ & $83 / 318$ & $83 / 319$ \\
\hline $\begin{array}{l}\text { SPECIFICATION TESTS }(p \text {-values) } \\
\text { (a) Sargan Test: } \\
\text { (b) Second Order Serial Correlation : }\end{array}$ & $\begin{array}{l}0.14 \\
0.17\end{array}$ & $\begin{array}{l}0.11 \\
0.66\end{array}$ & $\begin{array}{l}0.22 \\
0.96\end{array}$ & $\begin{array}{l}0.41 \\
0.72\end{array}$ & $\begin{array}{l}0.10 \\
0.61\end{array}$ \\
\hline
\end{tabular}

Note: The specification of the regression is identical to regression 2, Table 1 and 2 . The coefficients for the other control variables - secondary Schooling, Inflation, Openness to Trade and Government Size - are not reported 
Table A 3

Growth Effects of the Flexibility of Exchange Rate Regime

Robustness: Different Exchange Rate Regime Classifications

Dependent Variable: Growth Rate of Output per Worker

Estimation: 2-step system GMM estimation with Windmeijer (2004) Small Sample Robust Correction and Time Effects

(Standard errors are presented below the corresponding coefficient)

\begin{tabular}{|c|c|c|c|c|}
\hline Period: & $1970-2000$ & $1970-2000$ & $1970-2000$ & $1970-2000$ \\
\hline Unit of observation: & Non-o & erlapping 5-year avera & ges & \\
\hline Exchange Rate Classification & $\begin{array}{c}\text { De Facto } \\
\text { (RR Coarse) }\end{array}$ & $\begin{array}{c}\text { De Facto } \\
\text { ( Gosh and al.) }\end{array}$ & $\begin{array}{l}\text { De Facto } \\
\text { (Initial LYS) }\end{array}$ & $\begin{array}{c}\text { De Facto } \\
\text { (Modified LYS) }\end{array}$ \\
\hline Degree of the Exchange Flexibility & $-0.863 * *$ & $-2.280 * *$ & 1.628 & $-2.795 * *$ \\
\hline & 0.390 & 0.954 & 1.660 & 1.207 \\
\hline Financial Development & -1.270 & -0.740 & -0.462 & -1.017 \\
\hline & 0.963 & 0.990 & 0.500 & 1.100 \\
\hline Initial Output per Worker & -0.085 & -0.180 & -0.391 & $-1.076 *$ \\
\hline$(\log ($ initial output per worker $))$ & 0.430 & 0.489 & 0.630 & 0.639 \\
\hline Flexibility * Financial Development & $0.215 * *$ & $0.830 * *$ & -0.462 & $0.688 * *$ \\
\hline & 0.080 & 0.435 & 0.501 & 0.335 \\
\hline No. Countries / No. Observations & $79 / 421$ & $79 / 401$ & $79 / 418$ & $79 / 388$ \\
\hline SPECIFICATION TESTS ( $p$-values) & & & & \\
\hline (a) Sargan Test: & 0.24 & 0.585 & 0.31 & 0.35 \\
\hline (b) Second Order Serial Correlation : & 0.565 & 0.114 & 0.59 & 0.41 \\
\hline
\end{tabular}

** means significant at $5 \%$ and $*$ means significant at $10 \%$

Note: The specification of the regression is identical to regression 2, Table 1 and 2. The coefficients for the other

control variables - secondary Schooling, Inflation, Openness to Trade and Government Size - are not reported

Exchange Rate Flexibility Annual Coding:

De Facto (RR Coarse) : 13 ways Reinhart and Rogoff Coarse Classification (1: Fix to 13: Float)

De Facto (Gosh and al.): 3 ways Consensus Classification 1=Fix and Peg Regime, 2 = Intermediated Regime, 3 = Floating Regime

De Facto (Levy-Yeyati and al.): 4 ways Classification coded as (1: Fix; 2: Peg ; 3 Managed Float; 4 Float) 
Table A4

Growth Effects of Real Effective Exchange Rate Volatility

Robustness: Alternative Measure of Effective Exchange Rate Volatility

Dependent Variable: Growth Rate of Output per Worker

Estimation: 2-step system GMM estimation with Windmeijer (2004) Small Sample Robust Correction and Time Effects

(Standard errors are presented below the corresponding coefficient)

\begin{tabular}{|c|c|c|c|c|c|c|c|c|c|}
\hline \multirow[t]{2}{*}{$\begin{array}{l}\text { Period: } \\
\text { Unit of observation: }\end{array}$} & \multicolumn{4}{|c|}{$\begin{array}{c}1960-2000 \\
\text { Non-overlapping 5-year averages }\end{array}$} & \multicolumn{5}{|c|}{$\begin{array}{c}1975-2000 \\
\text { Non-overlapping 5-year averages }\end{array}$} \\
\hline & [A4.1] & {$[\mathrm{A} 4.2]$} & {$[\mathrm{A} 4.3]$} & [A4.4] & [A4.5] & {$[\mathrm{A} 4.6]$} & [A4.7] & {$[\mathrm{A} 4.8]$} & \\
\hline Real Exchange Rate Volatility & $\begin{array}{c}-0.968 * * \\
0.294\end{array}$ & & $\begin{array}{c}-3.28 * * \\
0.92\end{array}$ & & $\begin{array}{c}-0.831 * * \\
0.269\end{array}$ & & $\begin{array}{l}-3.985 * * \\
1.112\end{array}$ & & \\
\hline Nominal Exchange Rate Volatility & & $\begin{array}{r}0.037 \\
0.264\end{array}$ & & $\begin{array}{r}-0.134 \\
0.858\end{array}$ & & $\begin{array}{r}-0.277 \\
0.279\end{array}$ & & $\begin{array}{r}-2.491 * \\
1.163\end{array}$ & \\
\hline $\begin{array}{l}\text { Financial Development } \\
\text { (private domestic credit/GDP, in logs) }\end{array}$ & $\begin{array}{r}0.209 \\
0.529\end{array}$ & $\begin{array}{r}0.678 \\
0.543\end{array}$ & $\begin{array}{c}-1.576 * \\
0.811\end{array}$ & $\begin{array}{r}0.186 \\
0.658\end{array}$ & $\begin{array}{r}0.227 \\
0.45\end{array}$ & $\begin{array}{r}0.168 \\
0.692\end{array}$ & $\begin{array}{l}-2.64 * * \\
1.024\end{array}$ & $\begin{array}{r}-2.017 \\
0.763\end{array}$ & \\
\hline $\begin{array}{l}\text { Initial Output per Worker } \\
(\log (\text { initial output per worker }))\end{array}$ & $\begin{array}{r}-0.605 \\
0.502\end{array}$ & $\begin{array}{l}-0.719 * * \\
0.539\end{array}$ & $\begin{array}{r}-0.52 \\
0.489\end{array}$ & $\begin{array}{r}-0.702 \\
0.564\end{array}$ & $\begin{array}{c}0.574 * \\
0.33\end{array}$ & $\begin{array}{l}0.975 * \\
0.596\end{array}$ & $\begin{array}{l}1.081 * * \\
0.411\end{array}$ & $\begin{array}{r}1.363 \\
0.382\end{array}$ & ** \\
\hline Real Exchange Rate Volatility * Fina & ial Develop & & $\begin{array}{l}0.672 * * \\
0.24\end{array}$ & & & & $\begin{array}{l}0.739 * * \\
0.273\end{array}$ & & \\
\hline Nominal Exchange Rate Volatility $*$ & lancial Deve & nent & & $\begin{array}{r}0.065 \\
0.265\end{array}$ & & & & $\begin{array}{c}0.699 \\
0.32\end{array}$ & \\
\hline No. Countries / No. Observations & $74 / 421$ & $82 / 603$ & $74 / 421$ & $82 / 603$ & $73 / 335$ & $82 / 603$ & $73 / 335$ & $82 / 392$ & \\
\hline $\begin{array}{l}\text { SPECIFICATION TESTS ( } p \text {-values) } \\
\text { (a) Sargan Test: } \\
\text { (b) Second Order Serial Correlation : }\end{array}$ & $\begin{array}{l}0.75 \\
0.22\end{array}$ & $\begin{array}{l}0.14 \\
0.17\end{array}$ & $\begin{array}{l}0.65 \\
0.25\end{array}$ & $\begin{array}{r}0.1 \\
0.31\end{array}$ & $\begin{array}{l}0.74 \\
0.32\end{array}$ & $\begin{array}{l}0.61 \\
0.98\end{array}$ & $\begin{array}{l}0.32 \\
0.26\end{array}$ & $\begin{array}{l}0.52 \\
0.67\end{array}$ & \\
\hline
\end{tabular}

Note: The specification of the regression is identical to regression 1 and regression 2, Table 2. The coefficients for the other control variables - secondary Schooling, Inflation, Openness to Trade and Government Size - are not reported 
Table A 5

Growth Effects of the Flexibility of Exchange Rate Regime

Robustness: Different Measures of Financial Development

Dependent Variable: Growth Rate of Output per Worker

Estimation: 2-step system GMM estimation with Windmeijer (2004) Small Sample Robust Correction and Time Effects

(Standard errors are presented below the corresponding coefficient)

\begin{tabular}{|c|c|c|}
\hline $\begin{array}{l}\text { Period: } \\
\text { Unit of observation: }\end{array}$ & $\begin{array}{r}\text { 1970-2000 } \\
\text { Non-ove }\end{array}$ & $\begin{array}{l}70-2000 \\
\text { year averages }\end{array}$ \\
\hline $\begin{array}{l}\text { Degree of the Exchange Flexibility } \\
\text { (Reinhart and Rogoff clasisification) }\end{array}$ & $\begin{array}{r}-1.530 * * \\
0.510\end{array}$ & $\begin{array}{r}-1.602 * * \\
0.489\end{array}$ \\
\hline $\begin{array}{l}\text { Financial Development } \\
\text { (liquid liabilities/GDP) }\end{array}$ & $\begin{array}{r}-1.630 \\
1.210\end{array}$ & \\
\hline $\begin{array}{l}\text { Financial Development } \\
\text { (deposit money banks assets/GDP) }\end{array}$ & & $\begin{array}{c}-3.510 \\
1.970\end{array} *$ \\
\hline $\begin{array}{l}\text { Initial Output per Worker } \\
(\log (\text { initial output per worker }))\end{array}$ & $\begin{array}{r}0.410 \\
0.489\end{array}$ & $\begin{array}{l}0.860 \\
0.604\end{array}$ \\
\hline Flexibility * Financial Development & $\begin{array}{l}0.670 * * \\
0.290\end{array}$ & $\begin{array}{c}1.172 \\
0.707\end{array}$ \\
\hline No. Countries / No. Observations & $77 / 400$ & $77 / 404$ \\
\hline $\begin{array}{l}\text { SPECIFICATION TESTS ( } p \text {-values) } \\
\text { (a) Sargan Test: } \\
\text { (b) Second Order Serial Correlation : }\end{array}$ & $\begin{array}{l}0.342 \\
0.121\end{array}$ & $\begin{array}{l}0.523 \\
0.122\end{array}$ \\
\hline
\end{tabular}

** means significant at $5 \%$ and $*$ means significant at $10 \%$

Source: Authors' estimations

Note: The specification of the regression is identical to regression 3, Table 1 . The coefficients for the other control variables - secondary Schooling, Inflation, Openness to Trade and Government Size -

are not reported 
Table A 6

Growth Effects of the Flexibility of Exchange Rate Regime, Real Exchange Rate Volatility and Real Overvaluation: The Role of Distance to the Technological Frontier

Dependent Variable: Growth Rate of Output per Worker

Estimation: 2-step system GMM estimation with Windmeijer (2004) Small Sample Robust Correction and Time Effects (Standard errors are presented below the corresponding coefficient)

Period: 1960-2000

Unit of observation:

Non-overlapping 5 -year averages [5.1] [5.2]

Degree of the Exchange Flexibility

(Reinhart and Rogoff clasisification)

$-4.845 * *$

2.287

Real Exchange Rate Volatility

$-3.361 *$

1.797

Degree of the Real Exchange Rate Overvaluation

(log deviation from equilibrium exchange rate)

Financial Development

(private domestic credit/GDP, in logs)

Initial Output per Worker

$(\log ($ initial output per worker))

Flexibility*Initial Ouput Per Worker

-3.361
1.797

Exchange Rate Volatility*Initial Ouput Per Worker

$0.358 * *$

0.358
0.173

Real overvaluation*Initial Ouput Per Worker

$\begin{array}{ccc} & & -3.886 * * \\ & & 1.308 \\ & & \\ 0.640 * * & 1.180 * * & 0.593 * \\ 0.315 & 0.504 & 0.305 \\ & & \\ -1.474 * * & -1.830 * * & -3.074 \\ 0.641 & 0.595 & 2.126 \\ 0.568 * * & & \\ 0.265 & & \end{array}$

Control Variables:

Education

(secondary enrollment, in logs)

Trade Openness

(structure-adjusted trade volume/GDP, in logs)

Government Burden

(government consumption/GDP, in logs)

Lack of Price Stability

(inflation rate, in $\log$ [100+inf. rate])

Crisis

(banking or currency crisis dummy)

$0.401 * *$
0.180

Intercept

\begin{tabular}{ccc}
$1.505 * *$ & $2.470 * *$ & $1.518 * *$ \\
0.703 & 0.567 & 0.678 \\
& & \\
1.003 & 1.137 & $1.212 *$ \\
0.718 & 1.102 & 0.706 \\
& & \\
-0.952 & -0.795 & -1.327 \\
1.419 & 1.261 & 0.988 \\
& & \\
$-4.006 * *$ & -2.034 & $-3.801 * *$ \\
0.981 & 1.347 & 0.945 \\
& & \\
$-1.889 *$ & $-2.623 * *$ & $-1.908 *$ \\
1.064 & 1.184 & 1.050 \\
& & \\
$30.217 * *$ & $20.266 * *$ & $46.119 * *$ \\
6.837 & 7.668 & 16.205 \\
\hline $79 / 497$ & $83 / 548$ & $83 / 548$ \\
& & \\
0.595 & 0.180 & 0.423 \\
& & \\
0.000 & 0.000 & 0.000 \\
0.364 & 0.417 & 0.312 \\
& & \\
0.000 & 0.017 & 0.000 \\
0.014 & 0.000 & 0.000 \\
& &
\end{tabular}

No. Countries / No. Observations

SPECIFICATION TESTS ( $p$-values)

$\begin{array}{lccc}\begin{array}{l}\text { (a) Sargan Test: } \\ \text { (b) Serial Correlation : }\end{array} & 0.595 & 0.180 & 0.423 \\ \quad \text { First-Order } & 0.000 & 0.000 & 0.000 \\ \quad \text { Second-Order } & 0.364 & 0.417 & 0.312 \\ \text { WALD TESTS }(p \text {-values) } & & & \\ \text { Ho : Exchange Rate Measure Total Effect=0 } & 0.000 & 0.017 & 0.000 \\ \text { Ho :Initial Output Total Effect }=0 & 0.014 & 0.000 & 0.000\end{array}$

** means significant at $5 \%$ and $*$ means significant at $10 \%$

Source: Authors' estimations

THRESHOLD ANALYSIS

Growth enhancing effect of each exchange rate measure:

Ouput Per Worker greater than (1995 US\$)

5099

12063.39

16047

s.e.

\begin{tabular}{l}
$2321 \quad 5329 \quad 6477$ \\
\hline
\end{tabular}


Table A 7

Growth Effects of the Flexibility of Exchange Rate Regime

Robustness: Omission of a Continent

Dependent Variable: Growth Rate of Output per Worker

Estimation: 2-step system GMM estimation with Windmeijer (2004) Small Sample Robust Correction and Time Effects

(Standard errors are presented below the corresponding coefficient)

\begin{tabular}{|c|c|c|c|c|c|c|c|}
\hline Continent Omitted & $\begin{array}{r}\text { East Asia } \\
\text { and Pacific }\end{array}$ & $\begin{array}{l}\text { Europe and } \\
\text { Central Asia }\end{array}$ & $\begin{array}{r}\text { Latin America } \\
\text { and the } \\
\text { Caribbean }\end{array}$ & $\begin{array}{r}\text { Middle East } \\
\text { and North } \\
\text { Africa }\end{array}$ & $\begin{array}{r}\text { North } \\
\text { America }\end{array}$ & South Asia & $\begin{array}{r}\text { Sub-Saharan } \\
\text { Africa }\end{array}$ \\
\hline Period: & \multicolumn{7}{|c|}{$1970-2000$} \\
\hline \multirow[t]{2}{*}{ Unit of observation: } & \multicolumn{7}{|c|}{ Non-overlapping 5-year averages } \\
\hline & [1] & {$[2]$} & [3] & [4] & [5] & {$[6]$} & [7] \\
\hline Degree of the Exchange Flexibility & $-1.608^{*}$ & $-1.944 *$ & $-2.003 * *$ & $-1.931^{*}$ & $-2.200 *$ & $-2.373 *$ & $-1.442 *$ \\
\hline (Reinhart and Rogoff clasisification) & 0.702 & 1.136 & 0.621 & 0.959 & 0.859 & 0.998 & 0.801 \\
\hline Financial Development & -0.921 & -1.091 & -0.907 & -0.488 & -0.736 & $-1.437^{*}$ & -0.73 \\
\hline (private domestic credit/GDP, in logs) & 0.580 & 0.836 & 0.707 & 0.635 & 0.643 & 0.668 & 0.500 \\
\hline Initial Output per Worker & -0.273 & 0.703 & 0.013 & 0.376 & -0.509 & $0.668^{*}$ & 0.351 \\
\hline (log( initial output per worker)) & 0.388 & 0.541 & 0.455 & 0.405 & 0.387 & 0.378 & 0.532 \\
\hline \multirow[t]{2}{*}{ Flexibility * Financial Development } & $0.43 * *$ & $0.338 *$ & $0.253 * *$ & $0.36 *$ & $0.461 * *$ & $0.442 *$ & $0.293 *$ \\
\hline & 0.202 & 0.191 & 0.126 & 0.227 & 0.229 & 0.247 & 0.17 \\
\hline No. Observations & 364 & 321 & 315 & 376 & 409 & 403 & 338 \\
\hline No. Countries & 69 & 62 & 59 & 71 & 77 & 76 & 60 \\
\hline \multicolumn{8}{|l|}{ SPECIFICATION TESTS ( $p$-values) } \\
\hline (a) Sargan Test: & 0.61 & 0.65 & 0.7 & 0.53 & 0.46 & 0.46 & 0.66 \\
\hline (b) Second Order Serial Correlation: & 0.11 & 0.08 & 0.24 & 0.64 & 0.18 & 0.11 & 0.24 \\
\hline
\end{tabular}

** means significant at $5 \%$ and * means significant at $10 \%$

Table A 8

Growth Effects of the Real Effective Exchange Rate Volatility

Robustness: Omission of a Continent

Dependent Variable: Growth Rate of Output per Worker

Estimation: 2-step system GMM estimation with Windmeijer (2004) Small Sample Robust Correction and Time Effects

(Standard errors are presented below the corresponding coefficient)

\begin{tabular}{|c|c|c|c|c|c|c|c|}
\hline Continent Omitted & $\begin{array}{c}\text { East Asia } \\
\text { and Pacific }\end{array}$ & $\begin{array}{l}\text { Europe and } \\
\text { Central Asia }\end{array}$ & $\begin{array}{c}\text { Latin America } \\
\text { and the } \\
\text { Caribbean }\end{array}$ & $\begin{array}{l}\text { Middle East } \\
\text { and North } \\
\text { Africa }\end{array}$ & $\begin{array}{c}\text { North } \\
\text { America }\end{array}$ & South Asia & $\begin{array}{c}\text { Sub-Saharan } \\
\text { Africa }\end{array}$ \\
\hline Period: & \multirow{2}{*}{\multicolumn{7}{|c|}{$\begin{array}{l}\quad 1970-2000 \\
\text { Non-overlapping 5-year averages }\end{array}$}} \\
\hline \multirow[t]{2}{*}{ Unit of observation: } & & & & & & & \\
\hline & [1] & {$[2]$} & {$[3]$} & [4] & {$[5]$} & {$[6]$} & [7] \\
\hline \multirow[t]{2}{*}{ Real Exchange Rate Volatility } & $-3.324 *$ & $-4.139 *$ & $-3.606^{*}$ & $-4.484 *$ & $-2.448^{*}$ & $-5.247 * *$ & -1.828 \\
\hline & 1.573 & 1.884 & 1.731 & 1.876 & 1.374 & 1.691 & 1.627 \\
\hline Financial Development & $-2.076^{*}$ & -1.475 & -0.819 & -1.672 & -0.06 & $-2.543 * *$ & -0.315 \\
\hline (private domestic credit/GDP, in logs) & 1.259 & 1.344 & 1.296 & 1.405 & 0.897 & 1.247 & 1.127 \\
\hline Initial Output per Worker & 0.092 & 0.599 & -0.112 & 0.452 & -0.393 & -0.215 & -0.417 \\
\hline (log( initial output per worker)) & 0.515 & 0.659 & 0.553 & 0.511 & 0.531 & 0.493 & 0.615 \\
\hline \multirow[t]{2}{*}{ Exchange Rate Volatility * Financial Development } & $0.852 * *$ & $0.811 * *$ & $0.763^{*}$ & $1.029 * *$ & $0.635^{*}$ & $1.353^{* *}$ & 0.628 \\
\hline & 0.427 & 0.305 & 0.43 & 0.522 & 0.343 & 0.501 & 0.446 \\
\hline No. Observations & 412 & 367 & 349 & 428 & 463 & 451 & 380 \\
\hline No. Countries & 72 & 65 & 62 & 74 & 81 & 79 & 65 \\
\hline \multicolumn{8}{|l|}{ SPECIFICATION TESTS ( $p$-values) } \\
\hline (a) Sargan Test: & 0.37 & 0.47 & 0.65 & 0.19 & 0.24 & 0.15 & 0.48 \\
\hline (b) Second Order Serial Correlation : & 0.15 & 0.44 & 0.83 & 0.53 & 0.47 & 0.23 & 0.02 \\
\hline
\end{tabular}

Note: The specification of the regression is identical to regression 3, Table 1 and 2 . The coefficients for the other control variables - secondary

Schooling, Inflation, Openness to Trade and Government Size - are not reported 


\section{A Construction of the Real Exchange Rate Measures}

\section{A.1 Effective Real Exchange Rate}

We construct a trade-weighted effective exchange rate measure using the same time invariant trade weights as in Goldfajn and Valdes (1999): trade shares with major trade partners in 1985 from United Nation Trade Statistics. The list of major trade partners is given in Appendix B. As reliable data on labor costs are available only for a small subset of countries, we use the relative price level of consumption from international comparison of prices in Penn World Tables 6.1 in order to obtain real exchange rate values. The formula for the effective real exchange rate is:

$$
R E R_{i}^{S H}=\prod_{j=1}^{J}\left(P_{i} / P_{j}\right)^{w_{i, j}}
$$

where $i \in[1,83]$ and $j \in[1,14]$ index the country and its trade partners, $P_{i}$ and $P_{j}$ are the prices of the same basket of consumption goods in US dollars in country $i$ and country $j$ and $w_{i j}$ the weight of country $j$ in the trade exchange of country $i$.

An alternative measure of the effective real exchange rate is constructed using monthly CPI data from International Finance Statistics and monthly nominal exchange rate. As CPI is an index series normalized at 100 in 2000 for every countries, we obtained an index of real exchange rate:

$$
R E R_{i}^{c p i}=\prod_{j=1}^{J}\left(I_{i}^{c p i} / S_{i j} I_{j}^{c p i}\right)^{w_{i, j}}
$$

where $I_{i}^{c p i}$ is the CPI index in country $i$ and $S_{i j}$ is the nominal exchange rate between country $i$ and country $j$. A corresponding index of nominal effective exchange rate is computed as $E E R_{i}^{c p i}=\prod_{j=1}^{J}\left(1 / S_{i j}\right)^{w_{i, j}}$

\section{A.2 Real Exchange Rate Volatility}

The volatility of the real exchange rate used in the regression analysis is computed in each five year interval as the annual standard deviation of the growth rate of the effective real exchange rate: ${ }^{44}$

$$
\sigma_{i, t, t+5}=\operatorname{stdev}\left[\ln \left(R E R_{i t}^{S H}\right)-\ln \left(R E R_{i t-1}^{S H}\right)\right]
$$

An alternative measure of real exchange rate volatility and a measure of nominal exchange rate volatility are derived with the same formula using respectively the second measure of real

\footnotetext{
${ }^{44}$ Using growth rates to control for trending behavior in real exchange rate is standard in the literature (e.g. Hussain, Mody and Rogoff (2005))
} 
effective exchange rate $\left(R E R_{i}^{c p i}\right)$ and the corresponding measure of nominal effective exchange rate $\left(E E R_{i}^{c p i}\right)$.

\section{A.3 Real Overvaluation}

In order to construct a measure of real exchange rate overvaluation, we follow Dollar (1992). The equilibrium concept for the real exchange rate is Purchasing Power Parity adjusted from differences in the relative price of non tradeables to tradeables attributed to differences in factor endowments (i.e. the "Balassa-Samuelson" effect). Following Dollar (1992), we perform the following pooled OLS regression where income per capita and geographical dummies are used as proxies for factor endowments:

$$
\ln \left(R E R_{i, t}^{S H}\right)=\alpha+\beta_{t} d_{t}+\gamma \ln \left(Y_{i t}\right)+\delta l a c+\eta a f r i+\varepsilon_{i, t}
$$

where $d_{t}$ is a time dummy, $Y_{i t}$ GDP per capita, lac and afri continental dummies for LatinAmerican and African countries. Therefore, the real overvaluation measure is defined as:

$$
R O V I_{i, t}=100 \times\left[\left(\left(R E R_{i, t}^{S H}\right)-\widehat{R E R_{i, t}^{S} H}\right)\right]
$$

where $\widehat{R E R_{i, t}^{S} H}$ is obtained by taking the antilog of the predicted series in regression (17). ${ }^{45}$

An alternative measure of Real Overvaluation is derived following Goldfajn-Valdes (1999) as the log deviation of the CPI based measure of real exchange rate, $R E R_{i}^{C P I}$ from a stochastic trend constructed using a Hodrick-Prescott filter with a smoothing parameter $\lambda=10^{8}$.

\footnotetext{
${ }^{45}$ The estimation of equation (17) yields coef 


\section{Appendix B: List of 83 Countries}

\begin{tabular}{|c|c|c|}
\hline Algeria & Greece & Panama \\
\hline Argentina* & Guatemala & Papua New Guinea \\
\hline Australia* & Haiti & Paraguay \\
\hline Austria & Honduras & Peru \\
\hline Bangladesh & Iceland & Philippines \\
\hline Belgium & India & Portugal \\
\hline Bolivia & Indonesia & Senegal \\
\hline Botswana & Iran, Islamic Rep. & Sierra Leone \\
\hline Brazil* & Ireland & Singapore* \\
\hline Burkina Faso & Israel & South Africa* \\
\hline Canada & Italy* & Spain* \\
\hline Chile & Jamaica & Sri Lanka \\
\hline China & Japan* & Sweden \\
\hline Colombia & Jordan & Switzerland \\
\hline Congo, Dem. Rep. & Kenya & Syrian Arab Republic \\
\hline Congo, Rep. & Korea, Rep. & Thailand \\
\hline Costa Rica & Madagascar & Togo \\
\hline Cote d'Ivoire & Malawi & Trinidad and Tobago \\
\hline Denmark & Malaysia & Tunisia \\
\hline Dominican Republic & Mexico & Turkey \\
\hline Ecuador & Morocco & Uganda \\
\hline Egypt, Arab Rep. & Netherlands* & United Kingdom* \\
\hline El Salvador & New Zealand & United States* \\
\hline Finland & Nicaragua & Uruguay \\
\hline France* & Niger & Venezuela, RB \\
\hline Gambia, The & Nigeria & Zambia \\
\hline Germany* & Norway & Zimbabwe \\
\hline Ghana & Pakistan & \\
\hline
\end{tabular}

* Major trading partner 
Appendix C: Definitions and Sources of Variables Used in Regression Analysis

\begin{tabular}{|c|c|c|}
\hline Variable & Definition and Construction & Source \\
\hline GDP per capita & $\begin{array}{l}\text { Ratio of total GDP to total population. GDP is in } 1985 \text { PPP- } \\
\text { adjusted US\$. }\end{array}$ & $\begin{array}{l}\text { Authors' construction using Summers and } \\
\text { Heston (1991) and The World Bank } \\
\text { (2002). }\end{array}$ \\
\hline GDP per capita growth & Log difference of real GDP per capita. & $\begin{array}{l}\text { Authors' construction using Summers and } \\
\text { Heston (1991) and The World Bank } \\
\text { (2002). }\end{array}$ \\
\hline Initial GDP per capita & $\begin{array}{l}\text { Initial value of ratio of total GDP to total population. GDP is } \\
\text { in } 1985 \text { PPP-adjusted US\$. }\end{array}$ & $\begin{array}{l}\text { Authors' construction using Summers and } \\
\text { Heston (1991) and The World Bank } \\
\text { (2002). }\end{array}$ \\
\hline Output per worker & Real GDP per worker. & Summers and Heston (1991). \\
\hline Output per worker growth & Log difference of real output per worker. & $\begin{array}{l}\text { Authors' construction using Summers and } \\
\text { Heston (1991). }\end{array}$ \\
\hline Initial Output per worker & Initial value of Real GDP Chain per worker. & $\begin{array}{l}\text { Authors' construction using Summers and } \\
\text { Heston (1991). }\end{array}$ \\
\hline $\begin{array}{l}\text { Degree of exchange rate } \\
\text { flexibility }\end{array}$ & See Section 3.1 & Reinhart and Rogoff (2001). \\
\hline Education & $\begin{array}{l}\text { Ratio of total secondary enrollment, regardless of age, to the } \\
\text { population of the age group that officially corresponds to that } \\
\text { level of education. }\end{array}$ & $\begin{array}{l}\text { World Development Network (2002) and } \\
\text { The World Bank (2002). }\end{array}$ \\
\hline Private Credit & Ratio of domestic credit claims on private sector to GDP & $\begin{array}{l}\text { Author's calculations using data from IFS, } \\
\text { the publications of the Central Bank and } \\
\text { PWD. The method of calculations is based } \\
\text { on Beck, Demiguc-Kunt and Levine } \\
\text { (1999). }\end{array}$ \\
\hline Terms-of-Trade Growth & $\begin{array}{l}\text { Growth Rate of Terms of Trade Index. Terms of Trade Index } \\
\text { shows the national account exports price index divided by } \\
\text { imports price index with a } 1995 \text { base year. }\end{array}$ & $\begin{array}{l}\text { World Development Network (2002) and } \\
\text { The World Bank (2002). }\end{array}$ \\
\hline Trade Openness & $\begin{array}{l}\text { Residual of a regression of the log of the ratio of exports and } \\
\text { imports (in } 1995 \text { US\$) to GDP (in } 1995 \text { US\$), on the logs of } \\
\text { area and population, and dummies for oil exporting and for } \\
\text { landlocked countries. }\end{array}$ & $\begin{array}{l}\text { Author's calculations with data from } \\
\text { World Development Network (2002) and } \\
\text { The World Bank (2002). }\end{array}$ \\
\hline Government Size & Ratio of government consumption to GDP. & The World Bank (2002). \\
\hline CPI & Consumer price index $(2000=100)$ at the end of the year. & Author's calculations using data from IFS. \\
\hline Inflation rate & Annual \% change in CPI. & Author's calculations using data from IFS. \\
\hline Lack of Price Stability & $\log (100+$ inflation rate $)$ & Author's calculations using data from IFS. \\
\hline $\begin{array}{l}\text { Real Effective Exchange } \\
\text { Rate }\end{array}$ & See Appendix A & $\begin{array}{l}\text { Author's calculations using data from IFS } \\
\text { and UN Trade Statistics }\end{array}$ \\
\hline $\begin{array}{l}\text { Real Effective Exchange } \\
\text { Rate Volatility }\end{array}$ & See Appendix A & $\begin{array}{l}\text { Author's calculations with data from IFS } \\
\text { and UN Trade Statistics }\end{array}$ \\
\hline $\begin{array}{l}\text { Real Exchange Rate } \\
\text { Overvaluation }\end{array}$ & See Appendix A & $\begin{array}{l}\text { Author's calculations with data from IFS } \\
\text { and UN Trade Statistics }\end{array}$ \\
\hline Crisis dummy & $\begin{array}{l}\text { Number of years in which a country underwent a systemic } \\
\text { banking or a currency crisis, as a fraction of the number of } \\
\text { years in the corresponding period. }\end{array}$ & $\begin{array}{l}\text { Author's calculations using data from } \\
\text { Caprio and Klingebiel (1999), Kaminsky } \\
\text { and Reinhart (1998), and Gosh, Gulde and } \\
\text { Wolf (2000). }\end{array}$ \\
\hline \multirow[t]{3}{*}{ REGULATION INDEXES } & $\begin{array}{l}\text { Each index measures the intensity of the regulatory system on } \\
\text { a scale from } 0 \text { to } 1 \text { ( } 1 \text { representing the heaviest regulation). In } \\
\text { order to be able to combine all components, Loayza, Oviedo } \\
\text { and Serven (2004) apply the following standarization formula } \\
\text { to each one of them: }\end{array}$ & Loayza, Oviedo and Serven (2004). \\
\hline & $X=\frac{X_{i}-X_{\min }}{X_{\max }-X_{\min }}$ & \\
\hline & higher values of $\mathrm{X}$ indicate heavier regulation & \\
\hline Overall Regulation & $\begin{array}{l}\text { Average score of entry, financial market, labor, trade, fiscal } \\
\text { burden, contract enforcement and bankrupcy regulation } \\
\text { measures. }\end{array}$ & Loayza, Oviedo and Serven (2004). \\
\hline Product Market Regulation & $\begin{array}{l}\text { Average score of entry, financial market, trade, contract } \\
\text { enforcement and bankrupcy regulation measures. }\end{array}$ & Loayza, Oviedo and Serven (2004). \\
\hline Labor Regulation & $\begin{array}{l}\text { Combines the percentage of workers that belong to a union, } \\
\text { the minimun mandatory conditions and the degree of hiring } \\
\text { and firing flexibility granted. }\end{array}$ & Loayza, Oviedo and Serven (2004). \\
\hline Regulation of Entry & $\begin{array}{l}\text { Combines the number of legal steps required to register a new } \\
\text { business with an indicator of the overall legal burden of } \\
\text { registration and willingness of the government to facilitate the } \\
\text { process and intervene minimally. }\end{array}$ & Loayza, Oviedo and Serven (2004). \\
\hline Bankrupcy Regulation & $\begin{array}{l}\text { Regulation measures the efficiency of bankrupcy process by } \\
\text { combining the time and cost of insolvency, the enforcement } \\
\text { of priority of claims, the extent to which the efficient } \\
\text { outcome is achieved, and the degree of court involvement in } \\
\text { the process. }\end{array}$ & Loayza, Oviedo and Serven (2004). \\
\hline Period-specific Shifts & Time dummy variables. & Authors' construction. \\
\hline
\end{tabular}




\section{APPENDIX D : DESCRIPTIVE STATISTICS}

SAMPLE ANNUAL SUMMARY STATSITICS (1960-2000)

\begin{tabular}{|c|c|c|c|c|c|}
\hline Variable & Observations & Mean & Std. Deviation & Min & Max \\
\hline Flexibility of Exchange Rate & 3224 & 1.84 & 0.91 & 1.00 & 4.00 \\
\hline Private Credit/ GDP & 3587 & 34.88 & 36.07 & 0.01 & 236.98 \\
\hline Ouput per Worker & 3801 & 13277.66 & 18389.82 & 123.39 & 86957.22 \\
\hline Secondary Schooling & 3974 & 46.83 & 31.91 & 0.82 & 140.10 \\
\hline Adjusted Openness to Trade & 3377 & 0.00 & 0.57 & -2.82 & 1.83 \\
\hline Rate of Inflation & 3651 & 15.03 & 34.93 & -49.81 & 553.91 \\
\hline Government Expenditures to GDP & 3945 & 14.58 & 6.38 & 0.91 & 76.22 \\
\hline Dummy Banking or Currency Crisis & 3403 & 0.09 & 0.29 & 0.00 & 1.00 \\
\hline
\end{tabular}

SAMPLE ANNUAL CORRELATION (1960-2000)

\begin{tabular}{|c|c|c|c|c|c|c|c|c|}
\hline & $\begin{array}{l}\text { Flexibility of } \\
\text { Exchange Rate }\end{array}$ & $\begin{array}{c}\text { Private Credit/ } \\
\text { GDP }\end{array}$ & $\begin{array}{c}\text { Ouput per } \\
\text { Worker }\end{array}$ & $\begin{array}{l}\text { Secondary } \\
\text { Schooling }\end{array}$ & $\begin{array}{c}\text { Adjusted } \\
\text { Openness to } \\
\text { Trade }\end{array}$ & $\begin{array}{l}\text { Rate of } \\
\text { Inflation }\end{array}$ & $\begin{array}{c}\text { Government } \\
\text { Expenditures } \\
\text { to GDP }\end{array}$ & $\begin{array}{c}\text { Dummy } \\
\text { Crisis }\end{array}$ \\
\hline Flexibility of Exchange Rate & 1.00 & & & & & & & \\
\hline Private Credit/ GDP & 0.18 & 1.00 & & & & & & \\
\hline Ouput per Worker & 0.10 & 0.74 & 1.00 & & & & & \\
\hline Secondary Schooling & 0.11 & 0.32 & 0.42 & 1.00 & & & & \\
\hline Adjusted Openness to Trade & -0.02 & 0.09 & -0.07 & 0.19 & 1.00 & & & \\
\hline Rate of Inflation & 0.17 & -0.20 & -0.18 & -0.07 & -0.12 & 1.00 & & \\
\hline Government Expenditures to GDP & 0.06 & 0.28 & 0.44 & 0.35 & 0.24 & -0.08 & 1.00 & \\
\hline Dummy Banking or Currency Crisis & 0.09 & 0.06 & -0.07 & 0.07 & 0.06 & 0.08 & -0.05 & 1.00 \\
\hline
\end{tabular}

SAMPLE CORRELATION OF EXCHANGE RATE MEASURES (1960-2000; DATA IN FIVE-YEAR AVERAGE)

\begin{tabular}{lrrrrr} 
& $\begin{array}{c}\text { Exchange Rate } \\
\text { Flexibility }\end{array}$ & $\begin{array}{c}\text { Real Effective } \\
\text { Exchange Rate } \\
\text { Volatility* }\end{array}$ & $\begin{array}{c}\text { Real Effective } \\
\text { Exchange Rate } \\
\text { Volatility** }\end{array}$ & $\begin{array}{c}\text { Nominal Effective } \\
\text { Exchange Rate } \\
\text { Volatility** }\end{array}$ & $\begin{array}{c}\text { Real } \\
\text { Overvaluation }\end{array}$ \\
\hline Exchange Rate Flexibility & 1.00 & & & & \\
Real Effective Exchange Rate Volatility* & 0.22 & 1.00 & & & \\
Real Effective Exchange Rate Volatility** & 0.23 & 0.70 & 1.00 & & \\
Nominal Effective Exchange Rate Volatility** & 0.36 & 0.53 & 0.38 & -00 & 1.00 \\
Real Overvaluation & 0.09 & 0.13 & 0.11 & -0.05 & \\
\hline
\end{tabular}

* based on Penn World Table (see Appendix A)

**based on International Financial Statistics (see Appendix A)

Average Monthly Volatility of Real Effective

Exchange Rate by Exchange Rate Regime*

\begin{tabular}{ccc}
\hline Regime & Full sample & Excluding outliers** \\
\hline Fix & 1.61 & 1.53 \\
Peg & 1.60 & 1.60 \\
Managed Float & 2.84 & 2.56 \\
Float & 2.59 & 2.59 \\
Free Falling & 7.35 & 5.38 \\
\hline
\end{tabular}

*average by exchange rate regime of monthly volatility

monthly volatility = standard deviation of change in RER computed over a year

**excluding the $1 \%$ upper tail of each distribution of monthly volatility

\begin{tabular}{lcc}
\hline \hline \multicolumn{3}{l}{} \\
\hline $\begin{array}{l}\text { Average Annual Volatility (\%) of Real Effective Exchange Rate } \\
\text { and Selected Aggregate Variables* }\end{array}$ \\
\hline
\end{tabular}

